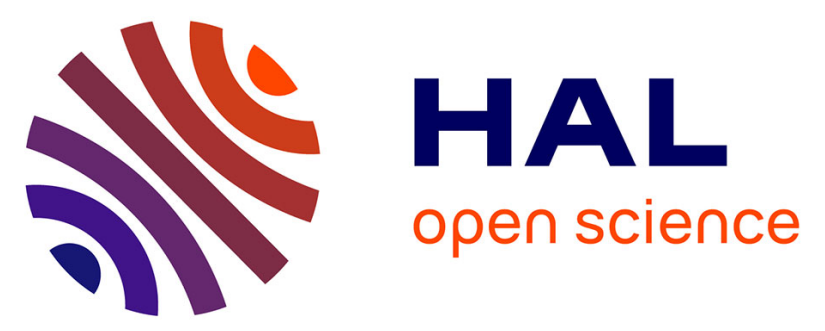

\title{
Geometry and kinematics of the Roisan-Cignana Shear Zone and the orogenic evolution of the Dent Blanche Tectonic System (Western Alps)
}

Paola Manzotti, Michele Zucali, Michel Ballevre, Martin Robyr, Martin Engi

\section{- To cite this version:}

Paola Manzotti, Michele Zucali, Michel Ballevre, Martin Robyr, Martin Engi. Geometry and kinematics of the Roisan-Cignana Shear Zone and the orogenic evolution of the Dent Blanche Tectonic System (Western Alps). Swiss Journal of Geosciences, 2014, 107 (1), pp.23-47. 10.1007/s00015-014-0157-9 . insu-01066025

\section{HAL Id: insu-01066025 \\ https://hal-insu.archives-ouvertes.fr/insu-01066025}

Submitted on 28 May 2021

HAL is a multi-disciplinary open access archive for the deposit and dissemination of scientific research documents, whether they are published or not. The documents may come from teaching and research institutions in France or abroad, or from public or private research centers.
L'archive ouverte pluridisciplinaire HAL, est destinée au dépôt et à la diffusion de documents scientifiques de niveau recherche, publiés ou non, émanant des établissements d'enseignement et de recherche français ou étrangers, des laboratoires publics ou privés. 


\title{
Geometry and kinematics of the Roisan-Cignana Shear Zone, and the orogenic evolution of the Dent Blanche Tectonic System (Western Alps)
}

\author{
Paola Manzotti • Michele Zucali • Michel Ballèvre • \\ Martin Robyr • Martin Engi
}

Received: 29 January 2013/Accepted: 28 February 2014/Published online: 18 April 2014

(C) Swiss Geological Society 2014

\begin{abstract}
The Dent Blanche Tectonic System (DBTS) is a composite thrust sheet derived from the previously thinned passive Adriatic continental margin. A kilometric high-strain zone, the Roisan-Cignana Shear Zone (RCSZ) defines the major tectonic boundary within the DBTS and separates it into two subunits, the Dent Blanche s.s. nappe to the northwest and the Mont Mary nappe to the southeast. Within this shear zone, tectonic slices of Mesozoic and preAlpine meta-sediments became amalgamated with continental basement rocks of the Adriatic margin. The occurrence of high pressure assemblages along the contact between these tectonic slices indicates that the amalgamation occurred prior to or during the subduction process, at an early stage of the Alpine orogenic cycle. Detailed mapping, petrographic and structural analysis show that the Roisan-Cignana Shear Zone results from several
\end{abstract}

Editorial Handling: S. Schmid \& A. G. Milnes.

Electronic supplementary material The online version of this article (doi:10.1007/s00015-014-0157-9) contains supplementary material, which is available to authorized users.

P. Manzotti $(\bowtie) \cdot$ M. Robyr $\cdot$ M. Engi

Institute of Geological Sciences, University of Bern,

Baltzerstrasse 1+3, 3012 Bern, Switzerland

e-mail: paola.manzotti@univ-rennes1.fr

P. Manzotti · M. Ballèvre

Géosciences Rennes, UMR-CNRS 6118, Université Rennes 1,

Campus de Beaulieu, 35042 Rennes, France

M. Zucali

Dipartimento di Scienze della Terra "Ardito Desio", Università degli Studi di Milano, Via Mangiagalli 34, 20133 Milan, Italy

M. Zucali

CNR-IDPA, Sezione di Milano, Via Mangiagalli 34,

20133 Milan, Italy superimposed Alpine structural and metamorphic stages. Subduction of the continental fragments is recorded by blueschist-facies deformation, whereas the Alpine collision is reflected by a greenschist facies overprint associated with the development of large-scale open folds. The postnappe evolution comprises the development of low-angle brittle faults, followed by large-scale folding (Vanzone phase) and finally brittle extensional faults. The RCSZ shows that fragments of continental crust had been torn off the passive continental margin prior to continental collision, thus recording the entire history of the orogenic cycle. The role of preceding Permo-Triassic lithospheric thinning, Jurassic rifting, and ablative subduction processes in controlling the removal of crustal fragments from the reactivated passive continental margin is discussed. Results of this study constrain the temporal sequence of the tectono-metamorphic processes involved in the assembly of the DBTS, but they also show limits on the interpretation. In particular it remains difficult to judge to what extent precollisional rifting at the Adriatic continental margin preconditioned the efficiency of convergent processes, i.e. accretion, subduction, and orogenic exhumation.

Keywords Austroalpine nappes .

Early Alpine tectono-metamorphic development .

Basement-cover relations · Italy $\cdot$ Switzerland

\section{Introduction}

In axial parts of subduction-collision orogens, fragments of continental crust are commonly found intermingled with meta-sediments and meta-ophiolites, both oceanic and continental units displaying evidence of high-pressure metamorphism. Such fragments of continental crust have 
been considered as explicit indicators showing that slices of passive continental margin were involved in the subduction process (Dal Piaz et al. 1972; Ernst et al. 2007). The Alps result from the collision between two major plates (the European plate to the north and the Adriatic plate to the south) after subduction of the intervening Piemont-Ligurian Ocean (e.g. Pfiffner 2009; Handy et al. 2010). Details of the history of these subduction-collision processes are recorded by the superposed deformational and metamorphic episodes. In the Western Alps, peak metamorphic conditions range from blueschist to eclogite facies in the continental units derived from the Adriatic margin (Compagnoni 1977). Ultra-high to high-pressure metamorphism (UHP-HP) has been recorded in the underlying oceanic units (Piemont-Ligurian Ocean, see Bearth 1967; Reinecke 1998; Groppo et al. 2009). However, adjacent units can display contrasting $\mathrm{P}-\mathrm{T}$ paths with highly variable early HP metamorphic records (Ballèvre and Merle 1993; Spalla et al. 1996; Bousquet et al. 2004; Beltrando et al. 2010a), revealing that the thermal structure associated to the early stages of the convergence has been reworked at a later stage. Therefore, the Western Alps hold an important place in the evolution of geological thinking about orogeny (e.g. Dal Piaz et al. 2001), not only on the mechanisms of nappe emplacement but also on the role of post-nappe folding during continuing convergence (e.g. Milnes 1974; Gosso et al. 1979).

The Dent Blanche Tectonic System (DBTS), referred to as Dent Blanche s.l. klippe by previous authors, is an excellent example of these processes. It has long been regarded as an erosional relic of the extensive Sesia-Dent Blanche nappes. The DBTS is a large composite thrust sheet, built up of relatively rigid bodies of Permian lower continental crust, intercalated with large, strongly deformed fragments of Permian upper continental crust and intensely sheared Mesozoic meta-sediments from the passive margin (Argand 1911; Diehl et al. 1952; Dal Piaz et al. 1971; Ballèvre et al. 1986). Individual continental slices now form different tectonic units (e.g. Valpelline Series) within the DBTS, bounded by Alpine shear zones.

Within the DBTS, the Roisan Zone is a sequence of Mesozoic sediments sandwiched between the pre-Alpine basement rocks of the DBTS (Mattirolo 1901; Argand 1906; Diehl et al. 1952; Elter 1960). Further mapping has shown that the Mesozoic sediments are indeed imbricated and folded together with intensely strained pre-Alpine orthogneisses, with the whole complex defining the RoisanCignana Shear Zone (Elter 1960; Canepa et al. 1990; De Giusti et al. 2003; Dal Piaz et al. 2010; Manzotti 2011). This kilometric high-strain zone divides the DBTS into two nappes. The present study aims specifically to examine the geometry, the kinematics and the metamorphic evolution of the Roisan-Cignana Shear Zone on the basis of detailed mapping and detailed petrographic and structural analysis. In addition, we critically assess to what extent pre-collisional rifting (Mohn et al. 2011) and post-collisional tectonic unroofing may account for the present position of the DBTS in the Western Alps, scrutinizing the evidence for the relevant processes, discerning their relative timing in each part of the evolution, but also showing the present limits of understanding.

\section{Geological setting}

In the Western Alps (Fig. 1), the oceanic units include dismembered ophiolites, with large volumes of serpentinized mantle peridotites, and sections largely composed of metaclastic and carbonate meta-sediments that are collectively interpreted as remnants of the Piemont-Ligurian Ocean (Elter 1971; Lemoine 1971; Lardeaux et al. 2006). Above this oceanic domain, several slices of pre-Alpine continental basement rocks now form independent thrust sheets (e.g. Dent Blanche, Mont Mary, Pillonet, Fig. 2) and as a whole they classically represent the Austroalpine in the Western Alps (Stutz and Masson 1938; Elter 1960). These slices are considered fragments of the frontal part of the Adriatic continental margin, thrust about $100 \mathrm{~km}$ to the north onto the oceanic domain (Dal Piaz et al. 1972; Dal Piaz 1999). The current position of these slices reflects a protracted succession of lithosphere-scale processes, involving the transition from a Mesozoic passive margin to Alpine convergence, with subduction, collision, and exhumation reorganizing the plate boundary.

The Zermatt-Saas and Combin Zones (in south-western Switzerland and in the Aosta region, Italy) represent remains of the Piemont-Ligurian Ocean (Figs. 1, 2, cf. Bearth 1967; Dal Piaz and Ernst 1978; Cartwright and Barnicoat 2002). The Zermatt-Saas Zone is a dismembered ophiolite sequence and comprises serpentinites, meta-gabbros, pillow lavas, and manganiferous cherts (Bearth 1967; Barnicoat and Fry 1986; Barnicoat et al. 1995). This unit experienced eclogite facies conditions during the Alpine orogeny (Bucher et al. 2005; Rebay et al. 2012). Blueschist facies assemblages locally overprint earlier eclogite facies minerals, and later greenschist facies assemblages are commonly found along tectonic contacts (Cartwright and Barnicoat 2002; Groppo et al. 2009). The Combin Zone comprises units derived either from an oceanic domain, consisting of ophiolitic rocks, manganiferous cherts and calcschists (Dal Piaz et al. 1979a; Baldelli et al. 1983), also referred to as the Tsaté nappe (Sartori 1987), or from Permo-Mesozoic sequences deposited on top of a continental basement, namely the quartzites and dolomitic marbles of presumed Triassic age of the Cime BianchePancherot Unit (Dal Piaz 1965, 1988; Vannay and 


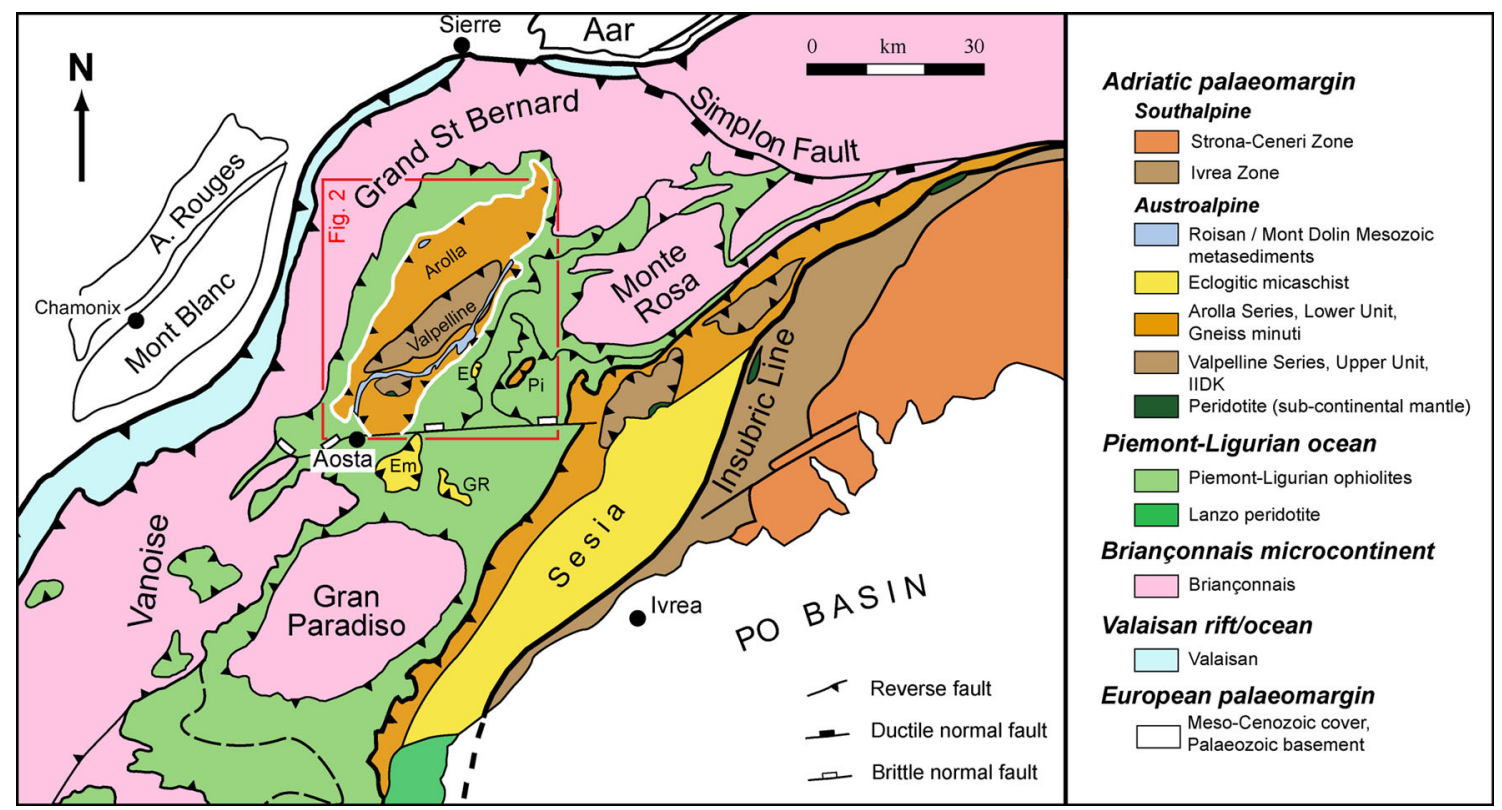

Fig. 1 Simplified tectonic map of the Western Alps of Switzerland and Italy (modified after Le Bayon and Ballèvre (2006)). The Dent Blanche Tectonic System is marked by a white line. E Etirol Levaz,
Em Emilius, GR Glacier-Rafray, Pi Pillonet. Because of their small sizes, the Santanel, Tour Ponton, and Acque Rosse basement slices are not shown in the map
Allemann 1990), detached from their pre-Alpine basement. The Combin Zone shows a pervasive greenschist-facies metamorphism, with scarce relicts of an earlier blueschist facies event during the Alpine evolution (Dal Piaz et al. 1979a; Caby 1981; Baldelli et al. 1983; Sperlich 1988).

The Austroalpine Domain comprises the internal Sesia Zone (Fig. 1) and a number of external slices (e.g. Dent Blanche, Mt. Emilius, cf. Stutz and Masson 1938; Elter 1960; Compagnoni et al. 1977). On the basis of their lithostratigraphic, structural and metamorphic characteristics, the external Austroalpine slices are grouped into northern and southern elements with respect to the Aosta valley and the east-west-trending Aosta-Ranzola fault (Dal Piaz 1999). The latter is an Oligocene-Neogene normal to transpressive fault system that lowered the northern block of the nappe pile (Stella 1905; Gouffon 1993; Dal Piaz 1999). The northern elements comprise (1) the Dent Blanche s.s. nappe (DB), the Mont Mary nappe (MM) and the Pillonet klippe (P on Fig. 2), all of which rest on the Combin Zone and show Alpine blueschist to greenschist facies metamorphism, (2) the Etirol Levaz slice, located at the boundary between the Saas-Zermatt and Combin Zones (Fig. 2) and characterized by a dominant Alpine eclogite facies (Kiénast 1983; Ballèvre et al. 1986; Beltrando et al. 2010b). The southern elements (Fig. 1, south of the Aosta fault) are represented by the Mt. Emilius, Glacier-Rafray, Santanel, Tour Ponton, and Acque Rosse slices, also displaying Alpine eclogite facies metamorphism (Argand 1911; Dal Piaz and Nervo 1971; Nervo and Polino 1976;
Dal Piaz et al. 1979b, 1983; Bearth et al. 1980; Ballèvre et al. 1986; Battiston et al. 1987; Pennacchioni 1990; Paganelli et al. 1995).

The Dent Blanche s.l. klippe, referred to here as the Dent Blanche Tectonic System (DBTS), constitutes the largest continental klippe now exposed above the surrounding oceanic domain (Fig. 2). It comprises two main subunits, i.e. the Dent Blanche s.s. nappe to the northwest and the Mont Mary nappe to the southeast. These two nappes are separated by a $25 \mathrm{~km}$ long lithologically heterogeneous shear zone, termed the Roisan-Cignana-ShearZone (Fig. 2; RCSZ) that contains Mesozoic-age metasediments previously referred to as the Roisan Zone.

The Dent Blanche s.s. nappe consists of a tectonic superposition of two continental sheets, the Valpelline Series and the Arolla Series (Argand 1906, 1908; Diehl et al. 1952), with remnants of a Mesozoic cover of presumed Austroalpine origin (likely of the Arolla Series), i.e. the Mont Dolin Series (Weidmann and Zaninetti 1974; Ayrton et al. 1982, see Fig. 2). The Valpelline Series is predominantly composed of pre-Alpine amphibolite to granulite facies meta-pelites, mafic and carbonate rocks (Nicot 1977; Gardien et al. 1994; Manzotti and Zucali 2013). A localized Alpine blueschist to greenschist facies overprint is recognizable (Diehl et al. 1952; Kiénast and Nicot 1971; De Leo et al. 1987). The Arolla Series mostly comprises Permian intrusive bodies (granite, diorite, and gabbro) (Fig. 2), which were metamorphosed and deformed into orthogneisses and locally converted to 
Fig. 2 Simplified geological map of the Dent Blanche Tectonic System (for location, see Fig. 1). White lines delimit the Dent Blanche (DB), Mont Mary (MM) and Pillonet

(P) slices. The red line marks the boundary of the RoisanCignana Shear Zone (RCSZ)

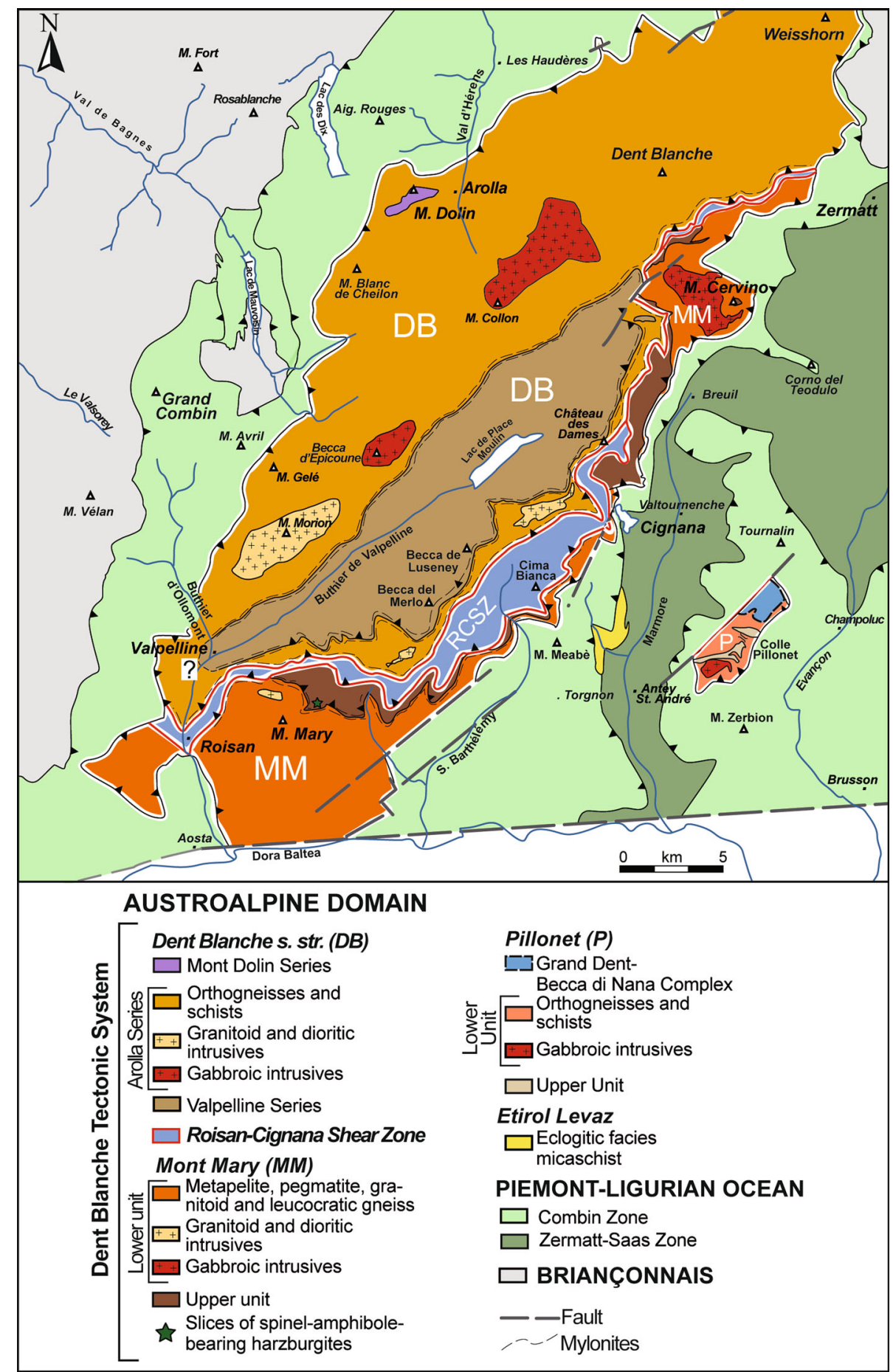

schists during the Alpine evolution (De Leo et al. 1987; Elter 1987; Pennacchioni and Guermani 1993; De Giusti et al. 2003; Roda and Zucali 2008). Substantial mafic to ultramafic layered igneous bodies occur in the Matterhorn (Cervino) and Mt. Collon-Dent de Bertol areas (Dal Piaz et al. 1977; Baletti et al. 2012; see Fig. 2). In contrast to the
Valpelline Series, the Arolla Series predominantly records the Alpine evolution; pre-Alpine high temperature-low pressure assemblages are only locally preserved in metresized pods of biotite-sillimanite-bearing gneiss and amphibolites occurring as roof-pendants within the undeformed granites (Diehl et al. 1952; Pennacchioni and 
Guermani 1993; Roda and Zucali 2008). These pods are interpreted as recording the high temperature conditions prevailing during Permo-Triassic lithospheric thinning, with large-scale intrusive magmatism (Monjoie et al. 2005; Roda and Zucali 2008). Following the pre-Alpine evolution, the rocks of the Arolla Series were subsequently transformed to blueschist facies orthogneiss (Roda and Zucali 2008). Whereas the age of the igneous protolith of the Arolla orthogneiss is well constrained (zircon $\mathrm{U}-\mathrm{Pb}$ : $289 \pm 2 \mathrm{Ma}$ (Bussy et al. 1998), the age of the high pressure Alpine stage remains uncertain. $\mathrm{K}-\mathrm{Ar}$ data (Hunziker 1974) for sodic amphibole (from glaucophane schists near Ollomont at the Combin-Dent Blanche contact) suggest an age of $48 \pm 15 \mathrm{Ma}$ for the high pressure metamorphism in the Arolla Series.

The Mt. Dolin Series crops out in the Val d'Hérens (Fig. 2). It consists of cargneules, Triassic and Liassic carbonates, and both mono- and polygenic breccias (Hagen 1948; Weidmann and Zaninetti 1974; Ayrton et al. 1982). The polygenic breccias have been considered Dogger in age by Weidmann and Zaninetti (1974) and by Ayrton et al. (1982). These authors underline the similarities of the Mont Dolin polygenic breccias with those of the Saluver Series (Lower Austroalpine), where tectono-sedimentary basement elements are also abundant (Roesli 1946; Finger 1978; Masini et al. 2011). Ayrton et al. (1982) described blue amphibole from the Mont Dolin Mesozoic cover sequence. In meta-sediments of this series, $\mathrm{K}-\mathrm{Ar}$ ages for white micas range between $55 \mathrm{Ma}$ and ca. $30 \mathrm{Ma}$ (Ayrton et al. 1982). The large spectrum of ages obtained probably reflects the reactivity of white mica upon cooling (e.g. Allaz et al. 2011) and isotopic resetting under greenschist facies conditions.

The Mont Mary nappe comprises two tectono-metamorphic units, i.e. the Upper and the Lower Units (Canepa et al. 1990; Dal Piaz et al. 2010) (Fig. 2). The Upper Unit shows strong similarities with the Valpelline Series of the Dent Blanche s.s. nappe (Diehl et al. 1952; Compagnoni et al. 1977). It consists of pre-Alpine amphibolite to granulite meta-pelites, mafic and carbonate rocks, and small slices of amphibole bearing spinel-harzburgite (Canepa et al. 1990; Bonetto et al. 2010). Locally the preAlpine high-grade assemblages have been partly retrogressed to greenschist facies conditions during the Alpine evolution. The main pre-Alpine amphibolite schistosity is deformed along mylonitic horizons that developed at relatively low pressure $\left(\mathrm{T}=510-580{ }^{\circ} \mathrm{C}, \mathrm{P}=0.25-0.45 \mathrm{GPa}\right.$; Pennacchioni and Cesare 1997; Pennacchioni et al. 2001). The Upper Unit also comprises a meta-gabbro body, outcropping at the Becca d'Aveille and characterized by a well developed Alpine greenschist overprint (Dal Piaz et al. 2010). The Lower Unit mainly consists of pre-Alpine amphibolite-facies meta-pelites and minor amphibolite, pegmatite, granitoid and leucocratic gneiss (Dal Piaz et al. 2010). All of the lithotypes show a heterogeneous Alpine greenschist facies overprint (Canepa et al. 1990; Dal Piaz et al. 2010).

The Dent Blanche s.s. nappe and the Mont Mary nappe are separated by the Roisan-Cignana Shear Zone (RCSZ), the main object of the present study. The RCSZ consists of strongly sheared remnants of Mesozoic and pre-Alpine sediments and mylonitized basement rocks derived from the adjacent Arolla Series and Lower Unit (Figs. 2, 3). The sheared Mesozoic sediments within the RCSZ are collectively known as the Roisan Zone (Diehl et al. 1952; Elter 1960). These meta-sediments contain a variety of dolomite marbles, classically attributed to the Triassic on the basis of lithology and poorly-preserved fossils (diploporacean algae according to Ballèvre et al. 1986). Recently, Ciarapica et al. (2010) identified diploporacean algae and a rich association of foraminifera preserved in dolomite marble that was attributed to the Late Triassic (Norian). Carbonate breccias, including dolomite clasts, calcschists and quartz-micaschists are also observed. In contrast to the poly-metamorphic basement, the metamorphic imprint found in the Roisan Zone is exclusively Alpine (Manzotti 2011). This zone is thus considered mono-metamorphic, but the metamorphic and tectonic evolution of these cover sequences has so far been poorly constrained. Several interpretations have been proposed to explain the occurrence and amalgamation of this Mesozoic cover into the polycyclic basement of the DBTS. The meta-sedimentary cover was originally viewed as a sequence belonging to the ophiolite-bearing calcschists of the Piemont-Ligurian Ocean (Argand 1906; Diehl et al. 1952). However, in contrast to the neighbouring Mesozoic meta-sediments of the Combin Zone, the RCSZ is devoid of ophiolites. It was then reinterpreted as the sedimentary cover of the Mont Mary unit (Elter 1960). Canepa et al. (1990) recently proposed that it is an independent tectonic unit composed of strongly mylonitized basement rocks (mainly derived from a granitoid basement) and of lenses and pods of the Mesozoic meta-sedimentary cover of these basements units. Our study of the RCSZ is largely in agreement with Canepa et al. (1990) and has resulted in the following general summary of its main rock units, from bottom to top:

- Calcschist, greenschist (prasinite) and serpentinite of the Combin Zone; part of the Piemont-Ligurian Ocean.

- $\mathrm{Ph}+$ sodic Amp \pm Chl-bearing schist and Amp \pm Grt-bearing orthogneiss derived from the Lower Unit of the Mont Mary nappe (in tectonized and mylonitic domains, showing high-strain and widespread chemical re-equilibration). 


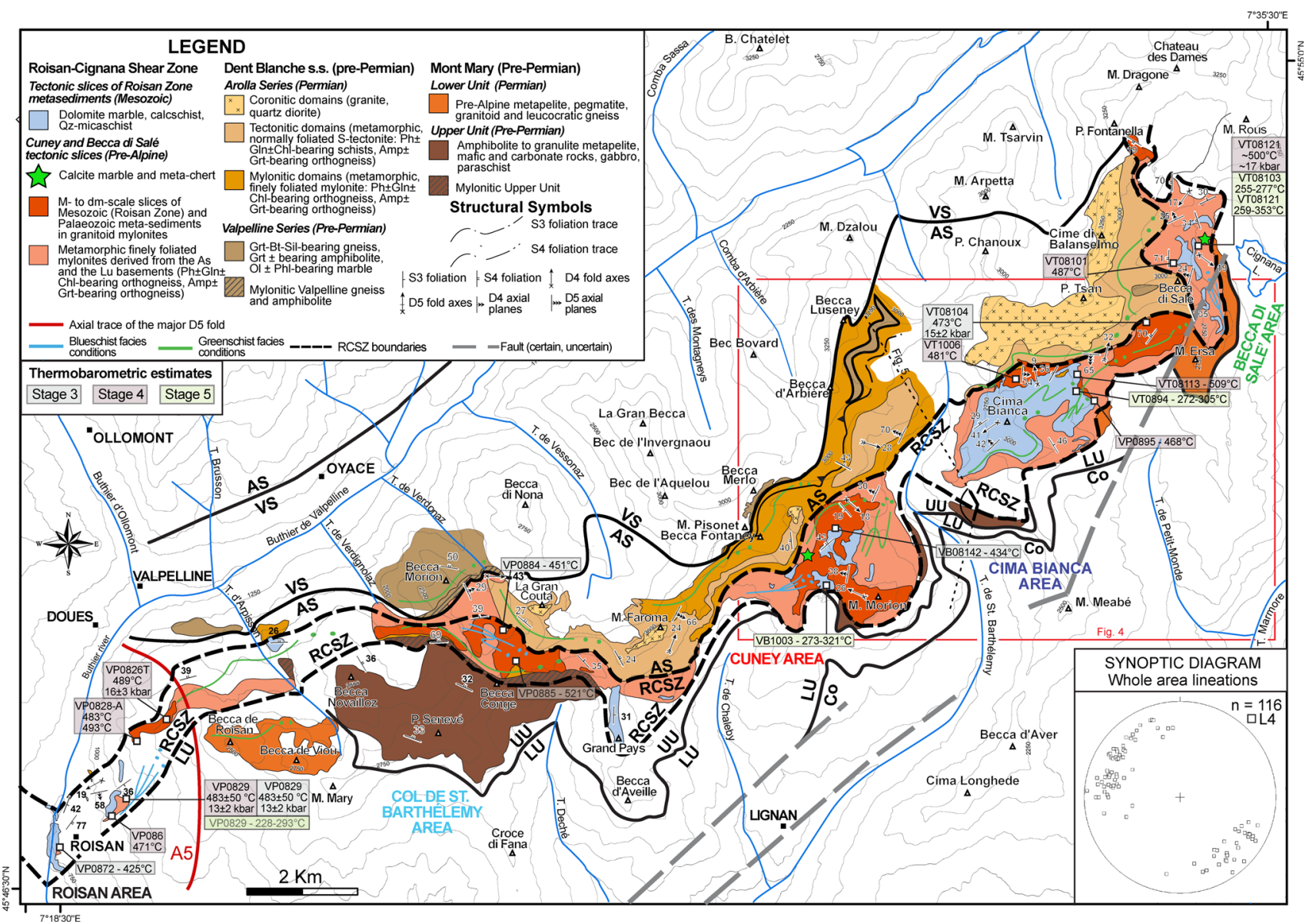

Fig. 3 Simplified structural and geological map of the studied Roisan-Cignana-Shear-Zone (RCSZ). The map also shows the distribution of all samples used in the RSCM study and for P-T estimations. Foliation traces depicted in blue are traced only where blueschist relicts have been found. The axial trace of the major D5 fold at Becca di Roisan is depicted in red. AS Arolla Series, VS

- Grt $\pm \mathrm{Bt} \pm$ Sil-bearing gneiss, Grt-bearing amphibolite and $\mathrm{Ol} \pm \mathrm{Phl}$-bearing marble derived from the Upper Unit of the Mont Mary nappe, cropping out from Becca Novailloz in the east to Becca Conge in the west (Canepa et al. 1990, see Fig. 3). Further east, mylonitized paraschist, outcropping on both sides of the St Barthélémy valley (Figs. 3, 4, 5), are also thought to derive from the Upper Unit of the Mont Mary nappe. Calcite marbles with interbedded cherts occur within paraschists (Sarrioles locality, Figs. 4, 5).

- Dolomite and calcite marble, calcschist, and quartzmicaschist derived from a Mesozoic cover referred to as the Roisan Zone.

- $\mathrm{Ph} \pm$ sodic Amp \pm Chl-bearing orthogneiss typical for tectonized and mylonitic domains characterized by thorough chemical re-equilibration and grading to granite and quartz diorite of the Arolla Series of the Dent Blanche s.s nappe, in coronitic domains, showing
Valpelline Series, RCSZ Roisan-Cignana Shear Zone, $U U$ Upper Unit, $L U$ Lower unit, $C o$ Combin Zone. The high-angle brittle faults are part of the Trois Ville System (Bistacchi and Massironi 2000). The inset shows lower hemisphere Schmidt (equal-area) projection of the stretching lineations developed during D4

very low strain, with very limited and local Alpine reequilibration.

\section{The Roisan-Cignana Shear Zone (RCSZ)}

\subsection{Tectonic units and rock types constituting the RCSZ}

The Roisan-Cignana-Shear-Zone (RCSZ) consists of a $25 \mathrm{~km}$ long high-strain zone, trending SW-NE. It is best exposed along the ridge between the Valpelline and Valtournenche valleys (Fig. 2). North of the Cignana Lake, the exact location of the RCSZ is difficult to ascertain (e.g. Elter 1960). However, based on detailed mapping of the Matterhorn (=Cervino) area (Bucher et al. 2003), Dal Piaz (1997) proposed a new geometry for the RCSZ, as depicted 


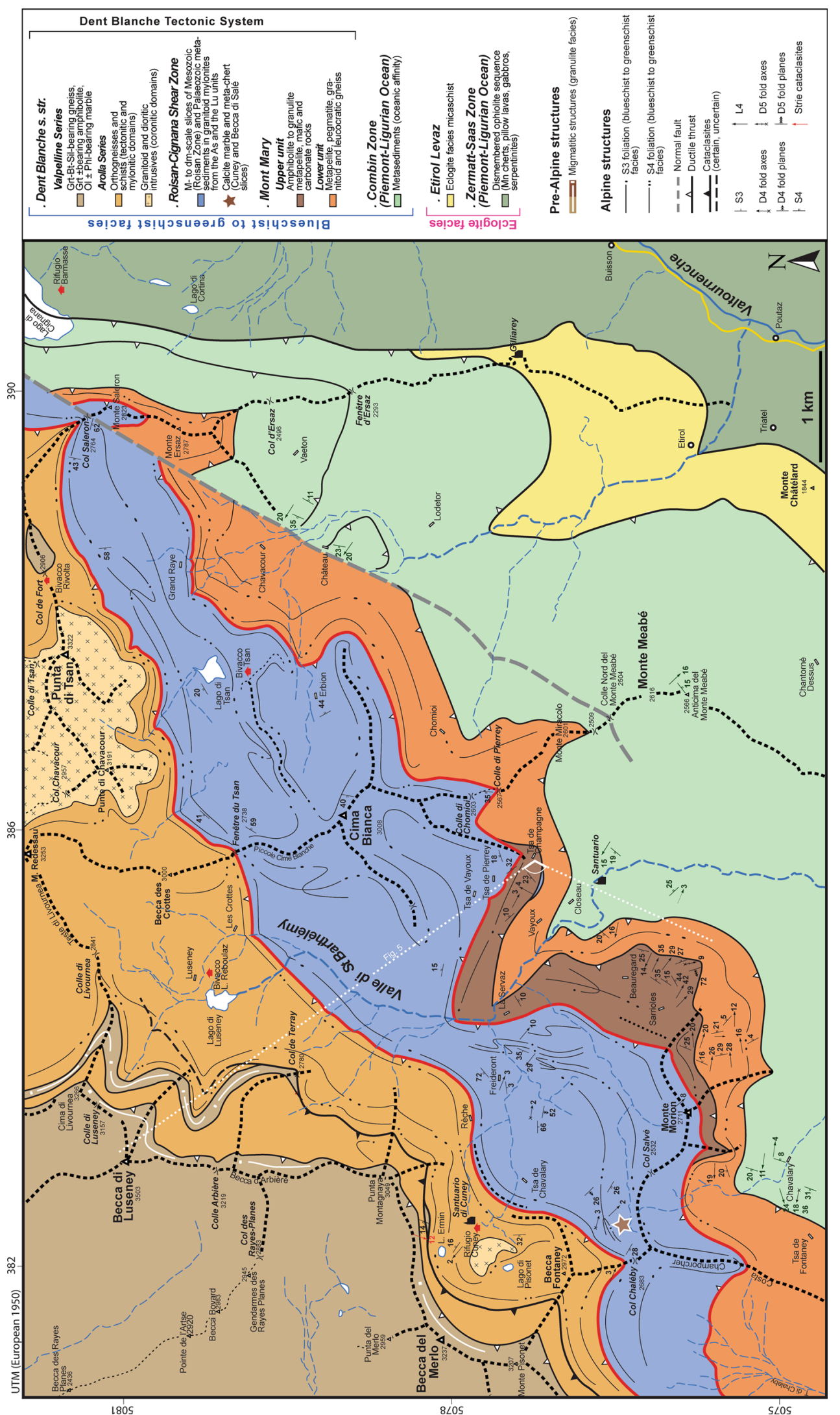

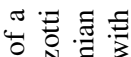

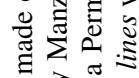

क्षे

马े :

N

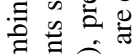

ठิ

o 해

. 해

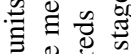

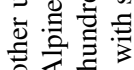

0 원

20.

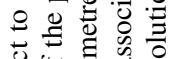

边

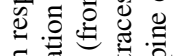

范范

N

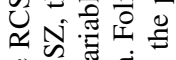

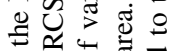

पै

응

응

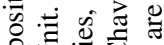

政

on 50

言造

के

के

op

江

记

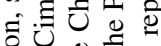

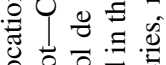

¿ ठ ठ

क्षै

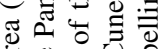

의

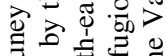

声司寻

o

पूँ

娄 \& 5

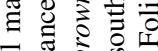

वृ

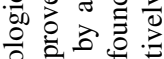

$\square .0$.

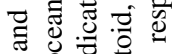

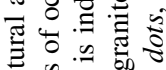

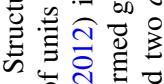

की पू

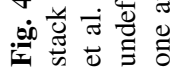



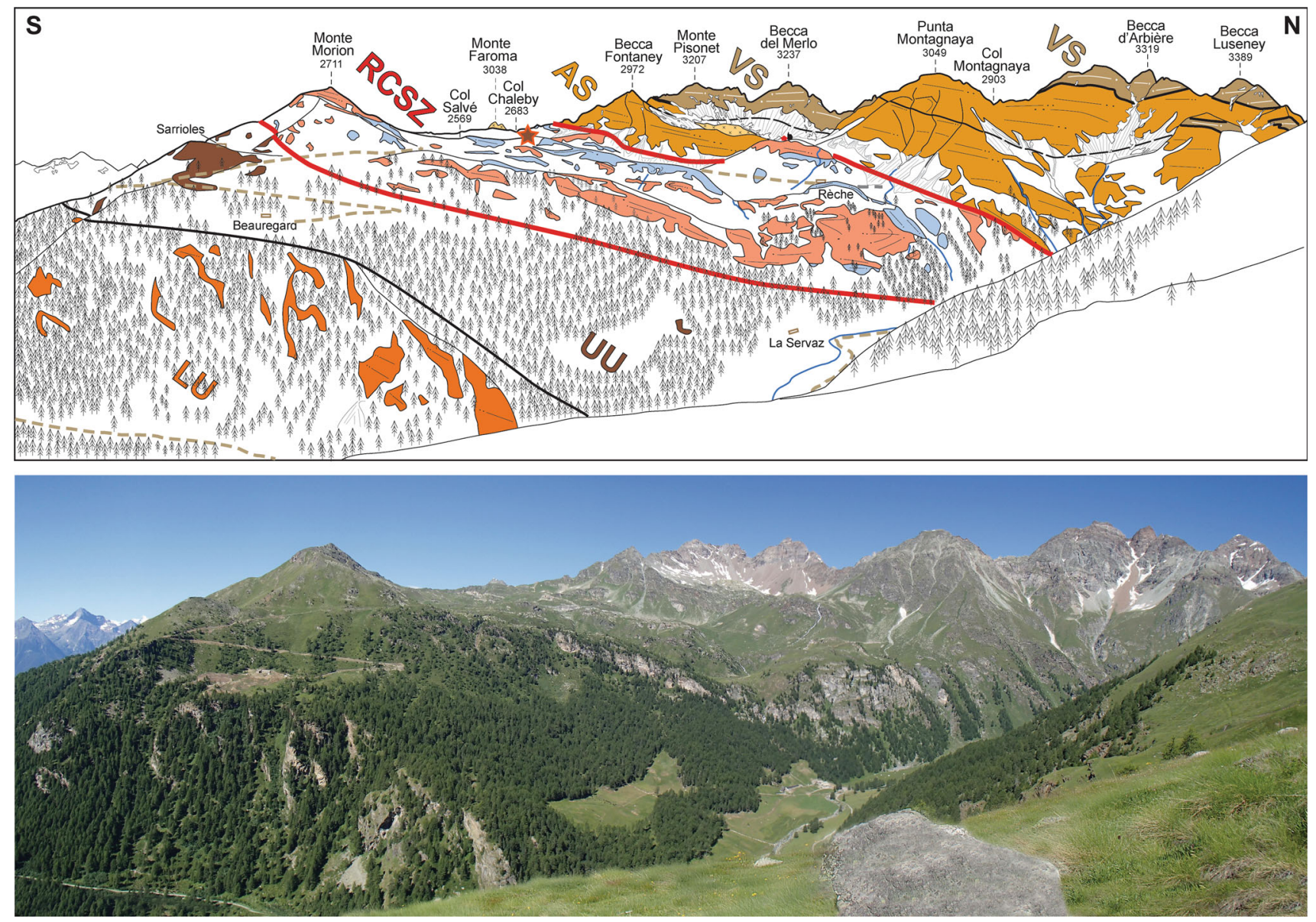

Fig. 5 Panorama of the Cuney area (looking west). The distance from Becca Luseney to Monte Morion is about $5 \mathrm{~km}$. Recognizable from bottom to top: the Lower Unit (LU) and Upper Unit (UU) of the Mont Mary nappe, the Roisan-Cignana Shear Zone (RCSZ), the
Arolla Series (AS) and the Valpelline Series (VS) of the Dent Blanche nappe. The brown star marks the pre-Alpine meta-sediments (Manzotti et al. 2012). For the legend and the approximate line of panorama, see Fig. 3 (black dashed line) and 4 (white dashed line)

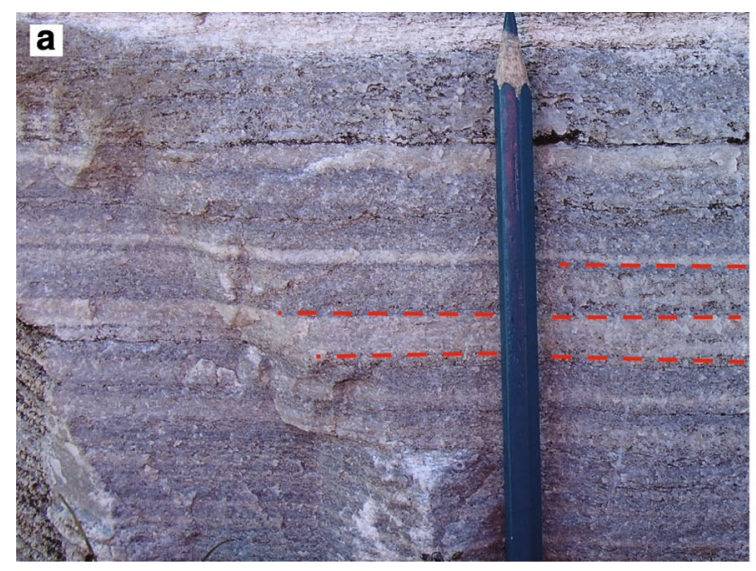

Fig. 6 Evidence of primary sedimentary features: a Alternating layers of calcite marble and quartzite. b Polygenic carbonate synsedimentary breccias in calcschist, successively affected by two

in Fig. 2. According to these studies, the Arolla and the Valpelline Series from the "Monte Cervino subunit" represent the northern extension of the Mont Mary nappe

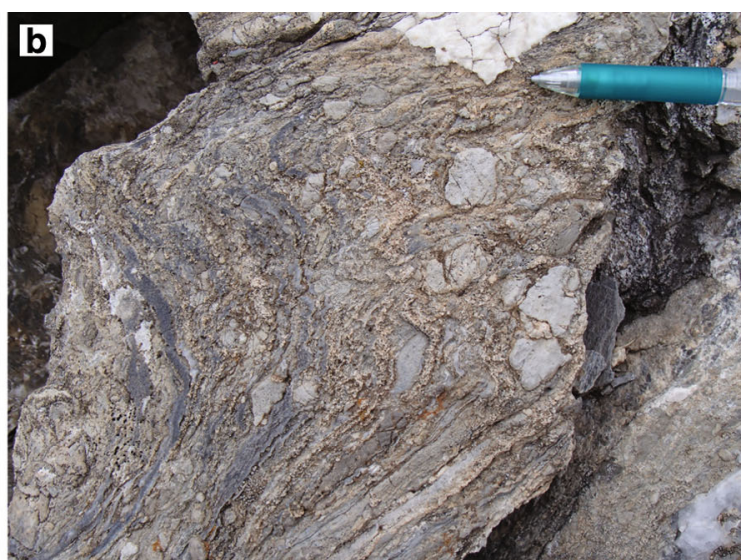

Alpine episodes of folding (stages 4 and 5). Field photos are located in Online Resource 1 (Table F)

(Lower and Upper Unit respectively). Dal Piaz (1976, 1999) described yet another part of the RCSZ located in the Pillonet klippe, named Grand Dent-Becca di Nana 
Fig. 7 a Layers and boudins of meta-chert in calcite marble. b Grt, Cpx (diopside) and Ttn assemblage in calcite marble (Cuney and Becca di Salé slices) (plane-polarized light). c Coronitic meta-granite (Arolla Series) with a preserved igneous texture: Kfs occurs as subhedral or euhedral centimetre-scale crystals (Cuney area). d Pl, K-fs and $\mathrm{Bt}$ assemblage in granite (crossed-polarized light) (Arolla Series). e Wm partially replaced Bt. $\mathbf{f}$ blueschist in the Lower Unit at the contact with the Roisan Zone. g S3 foliation is marked by the shape preferred orientation of sodic Amp and by Qz-Fsp lithons (plane-polarized light) (Arolla Series). Field photos are located in Online Resource 1 (Table F)

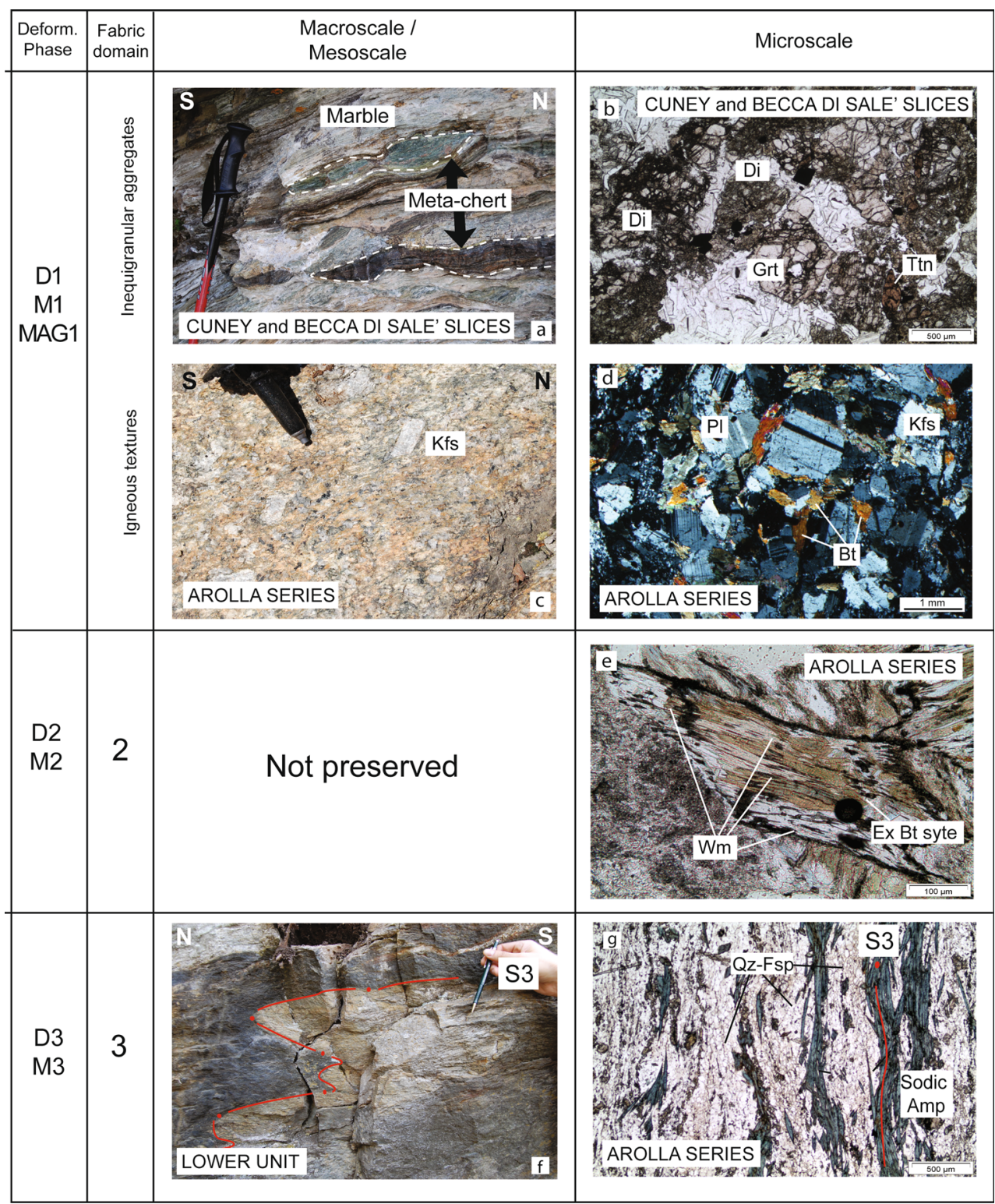

Complex (Fig. 2). However, the present study focuses on the portion of the RCSZ located between Roisan village and Cignana Lake (Figs. 2, 3, 4).

The RCSZ formed during several Alpine deformation phases and is characterized by tectonites and mylonites derived from protoliths of the Dent Blanche s.s. nappe (Arolla Series) and of the Mont Mary nappe (Lower and Upper Units) basements, from pre-Alpine meta-sediments and from a Mesozoic cover of unknown but presumably Austroalpine origin (Roisan Zone).

The Mesozoic Roisan Zone occurs only within the RCSZ and its thickness ranges from $30-50 \mathrm{~m}$ to 400-500 m. It is dismembered into bands and pods from metres up to $100 \mathrm{~m}$ in lateral extent, embedded within mylonites derived from the Arolla Series (Dent Blanche s.s. nappe) and from the Lower Unit (Mont Mary nappe).
The meta-sedimentary cover is best preserved as small pods $(1-10 \mathrm{~m})$ at the Col de $\mathrm{S}$. Barthélémy and Roisan village, and as large lenses (10-400 m) at Cima Bianca (Fig. 3).

Competent layers of dolomite marble are boudinaged, rotated and translated within a less competent matrix formed by mylonites derived from the Arolla Series of the Dent Blanche s.s. nappe and from the Lower Unit of the Mont Mary nappe and by quartz-micaschists that are also part of the Mesozoic Roisan Zone. Owing to the high strain, geometric relationships within the entire lithostratigraphic cover sequence have been progressively modified, hence the original sedimentary order is complete obliterated. However, thin (less than $1 \mathrm{~cm}$ ) layers of alternating calcite marble and quartzite (meta-sandstones) and polygenic carbonate syn-sedimentary breccias in 
Table 1 Schematic relationships between deformation and metamorphism in the lithologies studied (Roisan Zone and Arolla Series, Lower Unit)

\begin{tabular}{|c|c|c|c|c|}
\hline Stage & Age & Structure & Unit & $\begin{array}{l}\text { Metamorphic } \\
\text { conditions }\end{array}$ \\
\hline \multirow[t]{3}{*}{$\mathrm{D} 1+\mathrm{M} 1+\mathrm{MAGI}$} & \multirow[t]{3}{*}{ Pre-Alpine } & $\begin{array}{l}\text { Migmatitic structures } \\
\text { and foliation }\end{array}$ & VALPELLINE SERIES & $\begin{array}{l}\text { Granulite- } \\
\text { Amphibolite }\end{array}$ \\
\hline & & Inequigranular aggregates & CUNEY and BECCA DI SALE' SLICES & \multirow[t]{2}{*}{ Amphibolite } \\
\hline & & Igneous intrusion & AROLLA SERIES (coronitic domain) & \\
\hline $\mathrm{D} 2+\mathrm{M} 2$ & Pre-Alpine & Coronas & AROLLA SERIES (coronitic domain) & Greenschist \\
\hline \multirow[t]{3}{*}{$\mathrm{D} 3+\mathrm{M} 3$} & \multirow[t]{3}{*}{ Alpine } & \multirow[t]{3}{*}{$\mathrm{S} 3$} & AROLLA SERIES (mylonitic and tectonitic domains) & Blueschist \\
\hline & & & CUNEY and BECCA DI SALE' SLICES & Blueschist \\
\hline & & & ROISAN ZONE & $\begin{array}{l}\text { Blueschist?- } \\
\text { Greenschist }\end{array}$ \\
\hline \multirow[t]{3}{*}{$\mathrm{D} 4+\mathrm{M} 4$} & \multirow[t]{3}{*}{ Alpine } & \multirow[t]{3}{*}{ S4; F4, PA4 } & AROLLA SERIES (mylonitic and tectonitic domains) & Blueschist \\
\hline & & & CUNEY and BECCA DI SALE' SLICES & Blueschist \\
\hline & & & ROISAN ZONE & $\begin{array}{l}\text { Blueschist?- } \\
\text { Greenschist }\end{array}$ \\
\hline \multirow[t]{2}{*}{ D5 \pm M5 } & \multirow[t]{2}{*}{ Alpine } & \multirow[t]{2}{*}{ F5; PA5,S5 } & AROLLA SERIES (mylonitic and tectonitic domains) & \multirow[t]{2}{*}{ Greenschist } \\
\hline & & & ROISAN ZONE & \\
\hline D6 \pm M6 & Alpine & Fractures and veins & All lithologies & Greenschist \\
\hline
\end{tabular}

$S$ foliation, $F$ fold, $P A$ axial plane, $A$ fold axis

calcschist may represent evidence of primary sedimentological features (Fig. 6).

The scale of pervasive transposition that altered the original stratigraphy appears to be strongly dependent on the viscosity contrast and the relative thickness between layers of contrasting rheology. In the Roisan Zone, owing to the strong deformation that affected the cover sequence, the occurrence of Late Triassic microfossils and depositional structures is restricted to a few pods of undeformed dolomite marble (Ciarapica et al. 2010). Little information on the stratigraphy or overall distribution of sedimentary horizons is thus preserved.

Calcite marbles associated with discontinuous layers (10-30 cm thick) of meta-chert were reported by Ballèvre and Kiénast (1987) in the Becca di Salé area and interpreted as belonging to the Mesozoic sequences of the Roisan Zone (Fig. 7a). Recent investigations revealed that the same lithological types also occur in the Cuney area (Manzotti et al. 2012; see Figs. 4, 5). However, these metasediments record a Permian metamorphic imprint characterized by high temperature metamorphic assemblages (e.g. diopside in the marbles and garnet1 in the cherts, Manzotti et al. 2012). Moreover, the calcite marbles and the associated cherts are separated from the dolomite marbles of the Roisan Zone by thin sheets (1-2 m) of mylonitic orthogneisses. It thus appears that these calcite marbles and meta-cherts do not belong to the Roisan Zone (Fig. 7b) and they are referred to as Cuney and Becca di Salé slices. They represent slices of pre-Alpine lithologies inserted within the RCSZ. Because marbles and cherts have been found in the paraschists of the Upper Unit (Mont Mary nappe), we now propose that the Cuney and Becca di Salé slices represent pieces of the Upper Unit of the Mont Mary nappe, sheared into the RCSZ. The main criterion used to draw the lateral boundaries of the RCSZ (Figs. 2, 3, 4) is the presence of slices of Mesozoic and pre-Alpine metasediments in mylonites derived from protoliths of the Dent Blanche s.s. nappe (Arolla Series) and of the Mont Mary nappe (Lower and Upper Units).

\subsection{Tectonic evolution of the RCSZ}

Extensive field work in the RCSZ has been performed in order to unravel successive sets of mesostructures and their mutual relationships (Table 1), and the sequence of stages are described below. The orientation of fabric elements is plotted on Schmidt diagrams in Fig. 8 and a detailed summary of the metamorphic assemblages formed at different stages is reported in Table 2. Mineral abbreviations are after Whitney and Evans (2010), with Wm for white mica. In the following we describe the tectonic and metamorphic evolution, which can conveniently be subdivided into six deformation stages. Stages 1 and 2 are not associated to the development of the RCSZ, but they record the pre-Alpine evolution of the DBTS. This part of the evolution can still be recognized in the pre-Alpine metasediments slices found within the RCSZ and in the basement rocks of the Mont Mary and the Dent Blanche s.s. 
SCHMIDT PROJECTIONS (LOWER HEMISPHERE) OF FABRIC ELEMENTS ORIENTATIONS

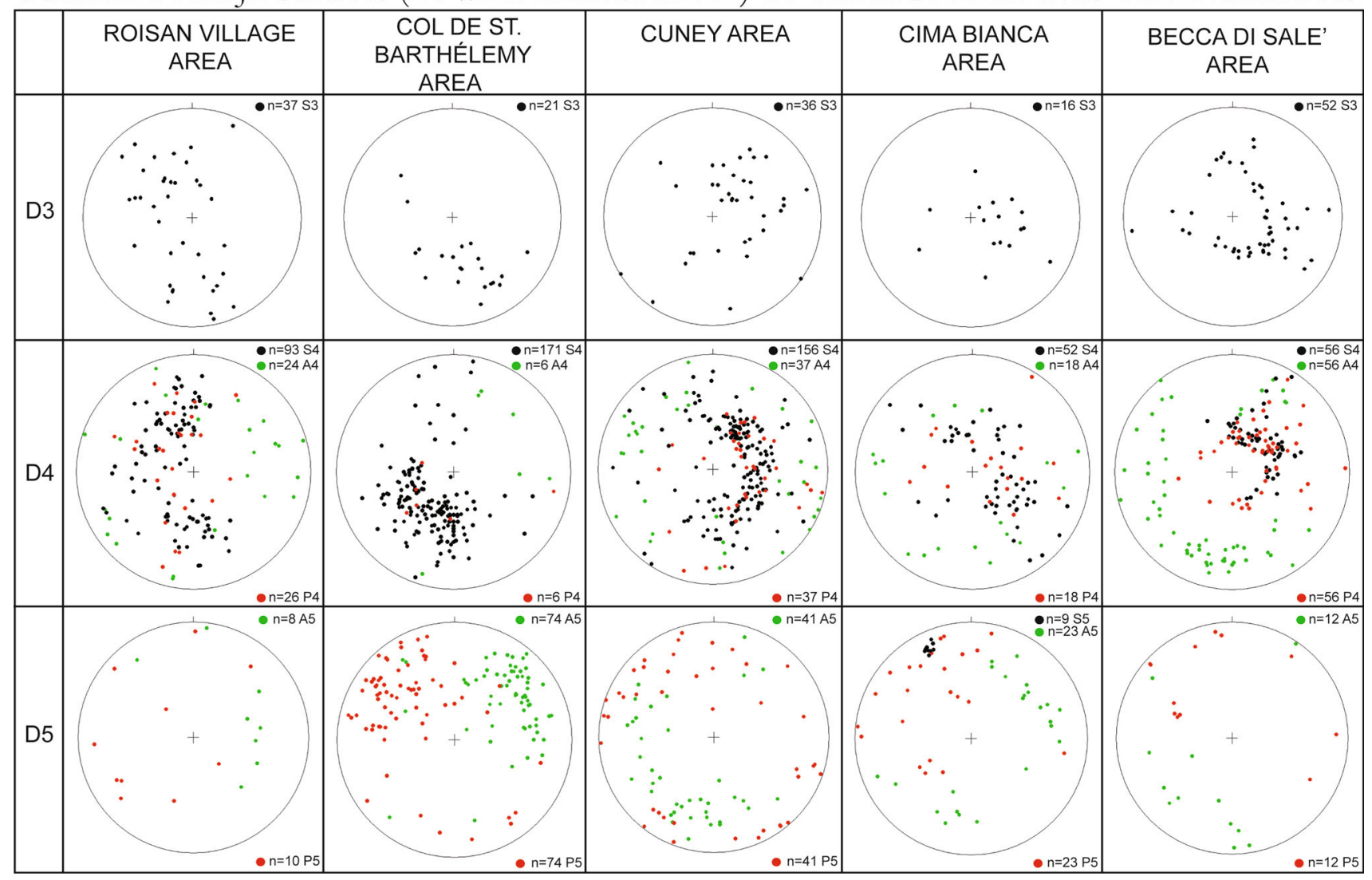

Fig. 8 Lower hemisphere Schmidt (equal-area) projections of structures in the Dent Blanche Tectonic System (Lower Unit, Upper Unit, Roisan Zone, pre-Alpine meta-sediments). Data of Alpine deformation stages are presented for different sub-areas (see Fig. 3): Roisan

nappes, involved in the RCSZ. The RCSZ formed during stages 3 and 4 at blueschist facies conditions and was subsequently refolded during stage 5 . Stages 3 and 4 are distinguished on the basis of the relative chronology of superimposed structures.

\subsubsection{Stage 1 (Permian)}

Strain gradients and heterogeneous partitioning of deformation and mineral transformations allowed for the preservation, at a range of scales, of pre-Alpine relics within all protolith types, notwithstanding the intense and polyphase deformation in the DBTS. In the area studied, the oldest stages are restricted to and well preserved in meta-pelites, mafics and carbonates of the Valpelline Series (Dent Blanche s.s. nappe) and of the Upper Unit (Mont Mary nappe). These retain granulite to amphibolite facies metamorphic assemblages (Gardien et al. 1994; Manzotti and Zucali 2013), which have recently been attributed to the Permian (zircon U-Pb age $\sim 275 \mathrm{Ma}$; Zucali et al. 2011; Manzotti 2012). village area, Col de St. Barthélemy area, Cuney area, Cima Bianca area, and Becca di Salé area. Poles to S5 foliation were observed in the Cima Bianca area only. Black dots poles to syn-metamorphic surface; red dots poles to axial surface of folds; green dots fold axes

The oldest imprint recognized in the Arolla Series (Dent Blanche s.s. nappe) was found in granitic to quartzdioritic intrusions. Bodies of undeformed Permian protoliths occur as kilometre- and hundreds of metre-scale pods (Fig. 7c), preserving igneous textures (Fig. 7d).

High grade metamorphic rocks occur in tectonic slices (Cuney and Becca di Salé slices; see Fig. 7a). In calcite marbles, the assemblage $\mathrm{Cal}+\mathrm{Qz}+\mathrm{Grt}+\mathrm{Di}+\mathrm{Tt}$ $\mathrm{n}+\mathrm{Aln}$ (Fig. 7b) reflects lower amphibolite facies conditions (Manzotti et al. 2012). In weakly deformed domains of Cuney and Becca di Salé, meta-cherts show mineral associations of Qz-Grt-Mn-Cum-Mag-Aln-Ap, again indicating amphibolite facies, probably at low pressure (Manzotti et al. 2012). Recent dating of allanite and zircon in meta-cherts and of titanite in calcite marbles yielded Permian and Triassic metamorphic ages (Manzotti et al. 2012).

\subsubsection{Stage 2 (Pre-Alpine?)}

This stage is visible in the Arolla Series (Dent Blanche s.s. nappe) at the microscale only, as described also for the 


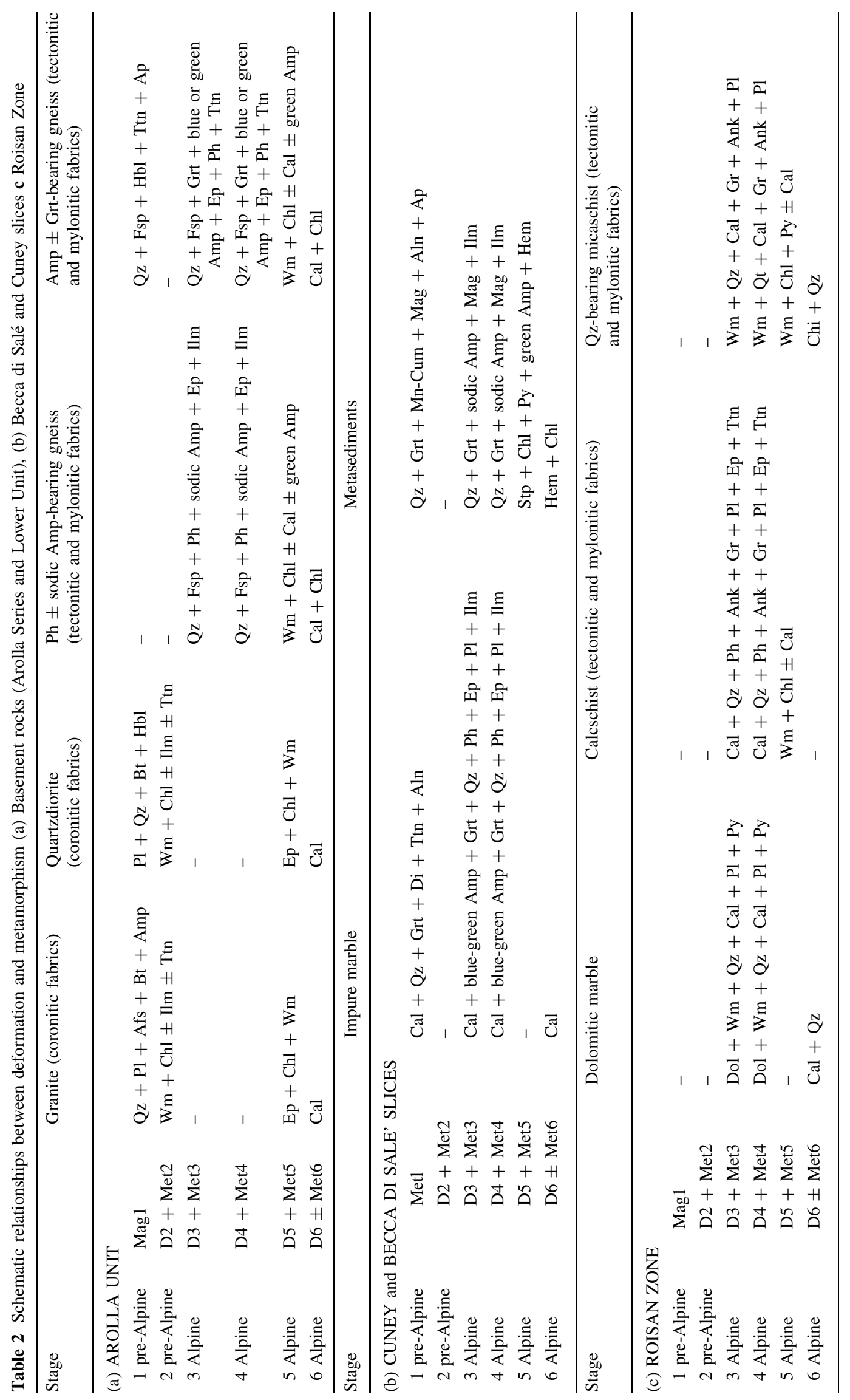


Mont Morion meta-granite (Roda and Zucali 2008; Malaspina et al. 2011), where igneous minerals (e.g. biotite) are rimmed or replaced by metamorphic minerals (white mica, titanite, chlorite, see Fig. 7e). Its weaker metamorphic grade (greenschist facies) distinguishes this stage from stage 1; importantly, its restricted local occurrence, in domains lacking pervasive Alpine deformation, indicates that stage 2 may represent a separate pre-Alpine stage. Dal Piaz et al. (1971) described similar pre-Alpine greenschist facies transformations in corresponding preAlpine protoliths (amphibolite facies gneisses and amphibolites) of the II DK (Seconda Zona DioritoKinzigitica) unit in the Sesia Zone.

\subsubsection{Stage 3 (Alpine)}

In the main lithologies (granite, quartzdiorite, orthogneiss, schist) of the Arolla Series (Dent Blanche s.s. nappe) and
Fig. 9 a Tens of metres-scale isoclinal D4 folds in dolomite. b S3 is marked by $\mathrm{Wm}$ and $\mathrm{Gr}$ and occurs as relic fold hinges, whereas $\mathrm{S} 4$ is the main planar structure (plane-polarized light). c A well-developed lineation (L4), defined by calcite aggregate and plunging to the southeast in a marble of the Upper Unit. d Dolomite clasts in Jurassic meta-sediments indicate a top-to-northwest transport. e Centimetre- to metre-scale D4 folds in calcschist. f Chl partially replaced sodic Amp (planepolarized light). g Differentiated crenulation cleavage in Arolla mylonitic gneiss: S5 is defined by cleavage domains and microlithons and is marked by $\mathrm{Wm}$ and Chl. h C'-type shear bands in Arolla gneiss (planepolarized light). i Tension gashes in a dolomite. $\mathbf{j}$ Fractures filled by Qz in a qz-micaschist (plane-polarized light). Field photos are located in Online Resource 1 (Table F)

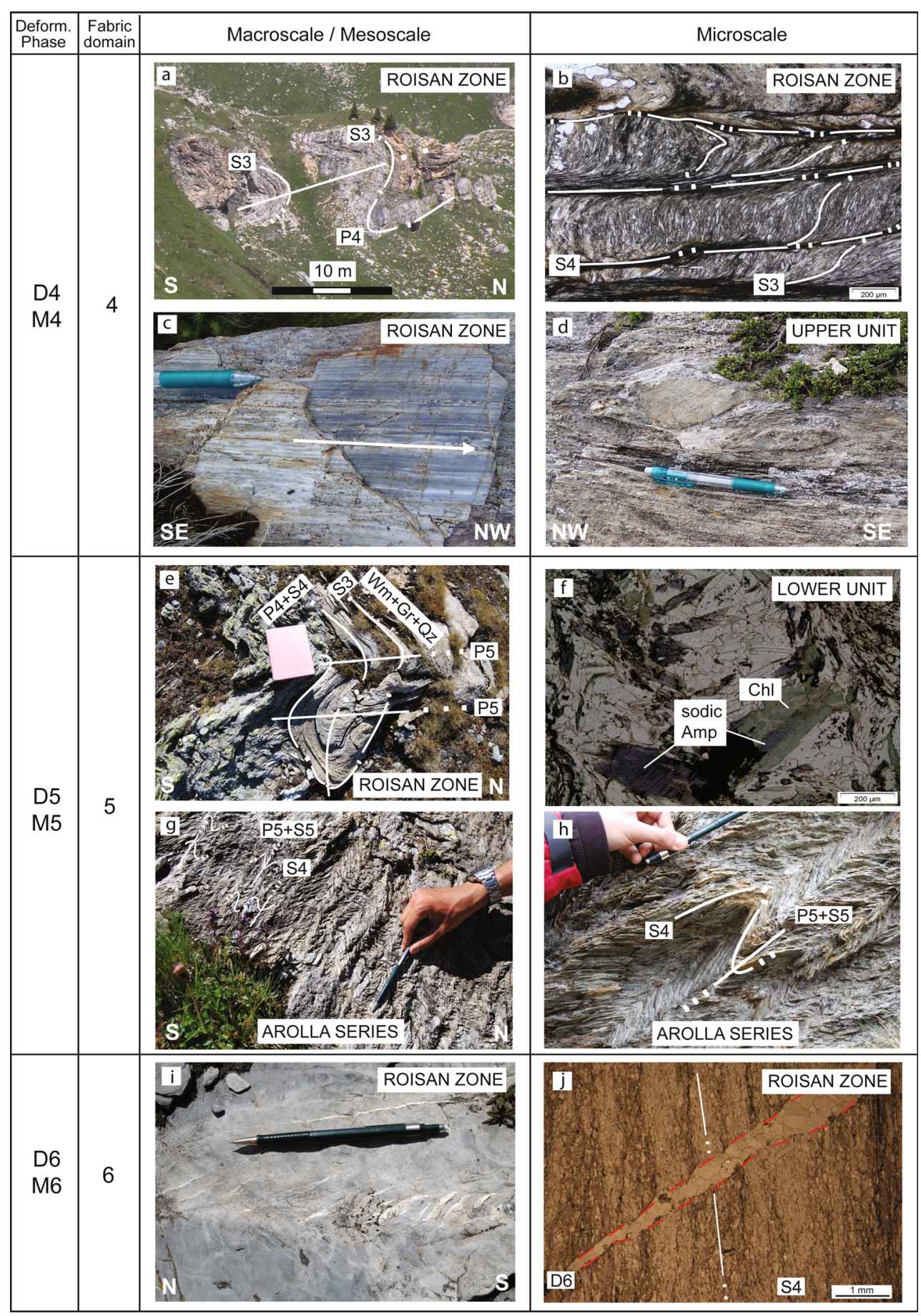


of the Lower Unit (Mont Mary nappe), stage 3 developed under blueschist facies conditions. In meta-granite, metaquartzdiorite, and in Amp \pm Grt-bearing gneiss, sodic and sodic-calcic amphibole overgrew magmatic amphibole (stage 1), and thin epidote rims developed around allanite. Single grains of epidote and phengite are also found in fractures cutting alkali feldspar.

The S3 foliation is the only preserved D3 structural element, well defined at the millimetre scale (Fig. 7f). Along the RCSZ, in the Arolla Series (Dent Blanche s.s. nappe) and in the Lower Unit (Mont Mary nappe) orthogneiss, S3 is marked by the shape preferred orientation of blueschist minerals, i.e. sodic amphibole and phengite, and by quartz-feldspar lithons (Fig. 7g). During this stage, garnet grew as small idioblastic crystals. Blueschist facies conditions are only rarely visible in the Arolla Series (Dent Blanche s.s. nappe) and in the Lower Unit (Mont Mary nappe), but they are found at several locations of the area studied; the imprint is clearest in shear zones affecting the basement-cover contact (Fig. 7f).

Also in the Cuney and Becca di Salé slices, S3 is defined by blueschist facies minerals, e.g. sodic amphibole (in meta-chert) and phengite (in calcite marble). A second generation of garnet grew both as late and discontinuous rims around garnet of stage 1 and as small idiomorphic crystals in quartz layers of meta-cherts.

In contrast to the Arolla Series (Dent Blanche s.s. nappe) and to the Lower Unit (Mont Mary nappe) and Cuney and Becca di Salé slices, the main lithologies of the Roisan Zone show no unequivocal metamorphic evidence of having reached blueschist facies during stage 3 . The S3 foliation is characterized by muscovite \pm phengite \pm graphite films, by quartz lithons in quartz-micaschist, and by the shape preferred orientation of phengite in calcschist. In dolomite marble, S3 is only recognizable at the mesoscale in D4-fold hinges, where these are outlined by dmthick bands of impure dolomite (Fig. 9a).

Owing to D4-folding, S3 orientations vary substantially, with dips $10^{\circ}-90^{\circ}$ towards the E-NE-SE (e.g. in the south-western part of the study area, near Roisan village and Col de St. Barthélémy, Fig. 8) or towards the W-NW (e.g. in the north-eastern part of the study area, near Cuney, Cima Bianca, and Becca di Salé, Fig. 8).

\subsubsection{Stage 4 (Alpine)}

D4 structures mainly consist of symmetric or asymmetric isoclinal folds, from centimetres to tens of metres in size, which transpose the S3 foliation into a new mylonitic foliation (Fig. 9b). S4 is the most pervasive planar structure at the scale of the outcrops studied and is expressed in fold hinges as an axial planar foliation, marked by the same metamorphic minerals as stage 3 (Table 2). The development of a penetrative mylonitic foliation is associated with the D4 deformation stage, large-scale structures of which are well preserved in the north-eastern part of the area (e.g. $100 \mathrm{~m}$ scale folds in dolomite marble pods, Fig. 9a). Strain heterogeneity allows the recognition of different stages of S4 development via a crenulation cleavage. Detailed mapping shows intense folding associated with this stage in the whole area: the S3 foliation was rotated by folding into an orientation approximately parallel to the axial plane of the F4 folds. Fold closures were locally dismembered by the development of the axial plane foliation S4 and by boudinage of dolomite marble.

Field observations indicate that strain and dynamic recrystallization related to this stage are preferentially localized in the Arolla Series (Dent Blanche s.s. nappe) and in the Lower Unit (Mont Mary nappe) lithologies as well as in quartz-micaschist and calcschist of the Roisan Zone.

Dolomite marble bodies of the Roisan Zone are stretched parallel to S4. Where dolomite pods are folded, they show a pervasive $\mathrm{S} 4$ foliation. The $\mathrm{X} / \mathrm{Y}$ ratio of dolomite marble pods increases up to $8: 1$ where the surrounding Arolla Series (Dent Blanche s.s. nappe) and Lower Unit (Mont Mary nappe) orthogneiss shows a well-developed S4 mylonitic foliation. Quartz-micaschist and calcschist of the Roisan Zone in contact with dolomite bodies also display a strong S4 mylonitic foliation.

Quartz porphyroblasts in the Arolla Series (Dent Blanche s.s.) and in the Lower Unit (Mont Mary nappe) orthogneiss and in quartz-micaschist of the Roisan Zone are locally elongated and flattened, with maximum extension parallel to the L4 lineation. Frequently old quartz grains appear partially or completely replaced by finegrained elongate aggregates of dynamically recrystallized quartz grains. Grain boundary migration and rotation recrystallization are the main deformation mechanisms that operated in the quartz. Similar progressive deformation and recrystallization of quartz were observed in the Arolla Series (Dent Blanche s.s. nappe) at the Comba di Crete Sèche, on the western side of the Valpelline valley (Menegon et al. 2008), where granitoids were extensively converted to tectonites and mylonites.

The axial plane foliation $\mathrm{S} 4$ dips $10^{\circ}-80^{\circ}$ towards the E-SE-NE (in the south-western part of the study area, near Roisan village and Col de St. Barthélemy, Fig. 8) and towards the W-SW-NW (in the north-eastern part of the study area, near Cuney, Cima Bianca, and Becca di Salé, Fig. 8). D4 axial surfaces display attitudes ranging $10^{\circ}-85^{\circ}$ in dip towards the E-SE-NE (in the south-western part of the study area, near Roisan village and Col de St. Barthélémy, Fig. 8) and towards the W-SW (in the northeastern part of the study area, near Cuney, Cima Bianca, 
and Becca di Salé, Fig. 8). D4 fold axes plunge towards E$\mathrm{NE}$ and W-NW (Fig. 8).

A stretching lineation (L4) is commonly defined by mineral aggregates of phengite \pm quartz \pm feldspar. Plunging gently to the NW or SE, depending upon later folding (synoptic diagram of Fig. 3), L4 is widely recognizable (1) in the $\mathrm{Ph} \pm$ sodic Amp-bearing orthogneiss of the Arolla Series (Dent Blanche s.s. nappe) and of the Lower Unit (Mont Mary nappe), (2) in the schist and marble of the Upper Unit (Mont Mary nappe, Fig. 9c), and (3) in the calcschist of the Roisan Zone. Kinematic markers (e.g. shear bands and dolomite clasts in Jurassic sediments) consistently indicate a top-to-NW transport (Fig. 9d).

\subsubsection{Stage 5 (Alpine)}

Stage 5 is associated with large scale folding of the RCSZ; including a major D5 recumbent fold which is observed in the Becca di Roisan area (panorama from Gignod village). In the main lithologies of the Arolla Series (Dent Blanche s.s. nappe), of the Lower Unit (Mont Mary nappe) and of the Roisan Zone, and in the Cuney and Becca di Salé slices, stage 5 developed under greenschist facies conditions. In the Arolla Series (Dent Blanche s.s. nappe) and Lower Unit (Mont Mary nappe) rocks, magmatic plagioclase was partially or completely replaced by muscovite and very finegrained zoisite-clinozoisite/albite symplectites. A new generation of chlorite and of pale green amphibole aggregates replaced the magmatic and earlier metamorphic amphiboles (Fig. 9f).

D5 structures consist of isoclinal and asymmetric folds, from centimetres to metres in size, which refold D4 folds (Fig. 9e). D5 folds are well developed in calcschist and quartz-micaschist of the Roisan Zone and in Arolla Series (Dent Blanche s.s. nappe) and Lower Unit (Mont Mary nappe) orthogneiss. Frequently, a differentiated crenulation cleavage with symmetric or asymmetric microfolds developed (Fig. 9g, h). Banding is a common feature of the Arolla Series (Dent Blanche s.s. nappe) and Lower Unit (Mont Mary nappe) orthogneiss and is related to the D5 crenulation cleavage. This stage is locally associated with the development of a new foliation S5, which is visible in mylonitic gneiss of the Arolla Series and of the Lower Unit and in quartzmicaschist of the Roisan Zone (Fig. 9g). S5 is defined by cleavage domains (in flanks of microfolds) and microlithons (in fold hinge areas) and is marked by muscovite, chlorite, and graphite.

D5 structures show a wide range of orientations, with the axial plane dip direction ranging from $9^{\circ}$ to $348^{\circ}$, with dip angles varying from $20^{\circ}$ to $89^{\circ}$ (Fig. 8). D5 fold axes trend from $5^{\circ}$ to $324^{\circ}$, and, near Cuney, the S5 foliation dips $50^{\circ}-70^{\circ}$ SE (Fig. 8).

\subsubsection{Stage 6 (late Alpine)}

This stage is characterized by fractures of variable orientations, notably affecting dolomite marble, in which tension gashes also occur (Fig. 9i). Millimetre-scale veins rich in calcite, quartz and/or chlorite developed during this brittle deformation phase in all of the lithologies (Fig. 9j).

\subsection{Alpine metamorphism in the RCSZ}

Determining the $\mathrm{P}-\mathrm{T}$ conditions of Alpine metamorphism in the RCSZ is a difficult task, as sensitive bulk-rock compositions (e.g. meta-basalts) are very rare, thus diagnostic mineral assemblages are lacking. The abundant carbonate rocks (dolomite as well as calcite marbles, calcschists) rarely contain suitable $\mathrm{P}-\mathrm{T}$ sensitive mineral assemblages. Where present, stable metamorphic assemblages that mark the different structures (e.g. foliations) were recorded in each rock type and chronologically ordered on the basis of a careful microstructural analysis (tectonometamorphic stages, Sect. 3.3, Table 2). Chemical analyses of minerals are shown in Online Resource 1 (Tables A-D; the distribution of all samples analysed in this contribution is reported in Fig. 3). P-T conditions that characterize the different stages (Table 3; Fig. 10, see also Online Resource 1, Table E and Figs 1-2) were determined considering the structural position occupied by each mineral or mineral pair analyzed.

In most lithologies from the Roisan Zone and in the preAlpine orthogneisses, albite is seen to have been stable throughout the metamorphic history, indicating an upper pressure limit defined by the reaction $\mathrm{Ab}=\mathrm{Jd}+\mathrm{Qz}$ (Holland 1980). However, a few samples were discovered, in which blue amphibole is abundant and albite absent. Because the microprobe analyses of sodic amphibole show very high $\mathrm{Fe}^{3+}$ contents (Online Resource 1, Table A), these may have been stabilized by higher oxygen fugacity at moderate pressures (Maruyama et al. 1986), possibly significantly lower than the $\mathrm{Ab}=\mathrm{Jd}+\mathrm{Qz}$ reaction.

Three rock types allowed quantitative thermobarometry pertinent to stages 3 and 4 to be carried out.

Graphite-bearing Qz-micaschists (quartz-minor calcite-phengite-ankerite-graphite-chlorite-albite-pyrite) and calcschists (quartz-calcite-phengite-ankerite-graphite-chlorite-albite-epidote-titanite) were studied using the RSCM (Raman Spectroscopy of Carbonaceous Material) method (Beyssac et al. 2002, 2003), which provides a maximum $T$ for each sample studied. A detailed description of the RSCM thermometry is included in Online Resource 1 (RSCM method and Table E). Maximum temperatures of $473 \pm 17{ }^{\circ} \mathrm{C}$ in Qz-micaschist and of $451 \pm 11{ }^{\circ} \mathrm{C}$ in calcschist of the Roisan Zone were derived for samples displaying stage 3 microstructures. Temperatures between 
Table 3 PT conditions for the rocks involved in the RCSZ and linking with the observed microstructures

\begin{tabular}{|c|c|c|c|c|c|}
\hline Stage & Rock/Unit & $\mathrm{T}^{\circ} \mathrm{C}$ (sample) & P kbar (sample) & \begin{tabular}{|l|} 
Method \\
\end{tabular} & Microstructures \\
\hline \multirow{5}{*}{3} & Qz-micaschist & $425 \pm 6$ (VP0872) & \multirow{4}{*}{$\begin{array}{c}15 \pm 2 \\
\text { (VT08104AT) }\end{array}$} & \multirow{4}{*}{$1-2$} & \\
\hline & (Roisan Zone) & $473 \pm 17$ (VT08104AT) & & & \\
\hline & Calcschist & 434 \pm 7 (VB08142) & & & \\
\hline & (Roisan Zone) & $451 \pm 11$ (VP0884) & & & \\
\hline & $\begin{array}{l}\text { Orthogneiss } \\
\qquad(A S-L U)\end{array}$ & $483 \pm 50$ (VP0829) & $\begin{array}{c}13 \pm 2 \\
\text { (VP0829) }\end{array}$ & $2-3$ & \\
\hline \multirow{11}{*}{4} & \multirow{6}{*}{$\begin{array}{l}\text { Qz-micaschist } \\
\text { (Roisan Zone) }\end{array}$} & $483 \pm 15$ (VP0828) & \multirow{9}{*}{$\begin{array}{c}16 \pm 3 \\
\text { (VP0826T) }\end{array}$} & \multirow{9}{*}{$1-2$} & \\
\hline & & $471 \pm 26$ (VP086) & & & \\
\hline & & 489 \pm 9 (VP0826T) & & & \\
\hline & & $493 \pm 9(\mathrm{VP0} 028 \mathrm{~A})$ & & & \\
\hline & & $521 \pm 27$ (VP0885) & & & \\
\hline & & 481 \pm 5 (VT1006) & & & \\
\hline & \multirow{3}{*}{$\begin{array}{c}\text { Calcschist } \\
\text { (Roisan Zone) }\end{array}$} & 468 \pm 11 (VT0895) & & & \multirow{5}{*}{ 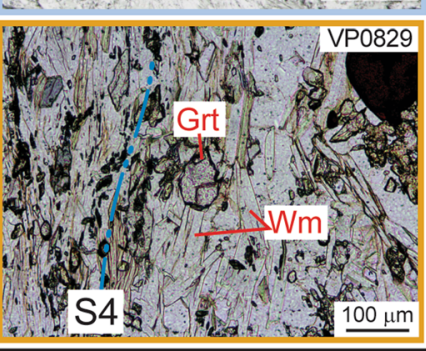 } \\
\hline & & $509 \pm 13$ (VT08113) & & & \\
\hline & & 487士21 (VT08101) & & & \\
\hline & $\begin{array}{l}\text { Orthogneiss } \\
(A S-L U)\end{array}$ & $480 \pm 50$ (VP0829) & $\begin{array}{c}13 \pm 2 \\
\text { (VP0829) }\end{array}$ & $2-3$ & \\
\hline & $\begin{array}{c}\text { Impure marble } \\
\text { (Cuney and Becca di Salé } \\
\text { slices) }\end{array}$ & 500 (VT08121) & $\begin{array}{c}\sim 17 \\
\text { (VT08121) }\end{array}$ & 2 & \\
\hline \multirow{4}{*}{5} & $\begin{array}{l}\text { Qz-micaschist } \\
\text { (Roisan Zone) }\end{array}$ & \begin{tabular}{|l}
$272-321$ \\
(VB1003-VT0894) \\
\end{tabular} & $\sim 4$ & \multirow{4}{*}{4} & \multirow{4}{*}{ 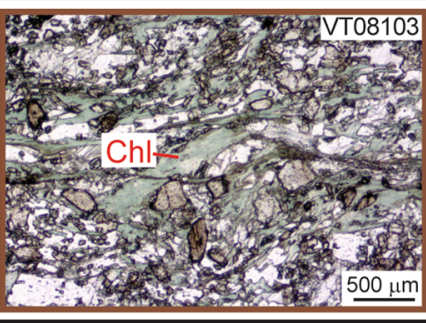 } \\
\hline & $\begin{array}{l}\text { Orthogneiss } \\
\qquad(A S-L U)\end{array}$ & 228-293 (VP0829) & $\sim 4$ & & \\
\hline & $\begin{array}{c}\text { Meta-chert } \\
\text { (Cuney and Becca di Salé } \\
\text { slices) }\end{array}$ & 255-277 (VT08103) & $\sim 4$ & & \\
\hline & $\begin{array}{c}\text { Impure marble } \\
\text { (Cuney and Becca di Salé } \\
\text { slices) }\end{array}$ & 259-353 (VT08121) & $\sim 4$ & & \\
\hline
\end{tabular}

Coloured boundaries around figures: light blue Roisan Zone; orange Arolla Series and Lower Unit, brown Cuney and Becca di Salé slices. Reference of methods used: (1) Gr thermometer (Beyssac et al. 2002); (2) Barometer (Dubacq et al. 2010); (3) Grt-Wm thermometer (Wu et al. 2002); (4) AlIV in Chl (Vidal et al. 2005, 2006)

470 and $521{ }^{\circ} \mathrm{C}$ were obtained in Qz-micaschist, and between 467 and $509{ }^{\circ} \mathrm{C}$ in calcschist (Roisan Zone); these pertain to samples displaying stage 4 microstructures.

Combined with the composition of coexisting phengite, maximum pressures can be estimated.

1. For the Roisan Zone, the phengite-quartz-water method of Dubacq et al. (2010) indicates maximum pressures of $15 \pm 2 \mathrm{kbar}$ and of $16 \pm 3 \mathrm{kbar}$ for stages 3 and 4, respectively (Online Resource 1, Fig. 1).

2. Strongly deformed orthogneiss containing the assemblage quartz-phengite-blue amphibole \pm garnet \pm chlorite occurs in the Arolla Series and Lower Unit rocks involved in the RCSZ. S3 and S4 structures, developed during stages 3 and 4 respectively, are clearly distinguishable. Garnet-phengite mineral pairs (Wu et al. 2002) of stages 3 and 4 in Arolla Series (Dent Blanche s.s. nappe) and Lower Unit (Mont Mary nappe) orthogneisses indicate temperatures of $483 \pm 50{ }^{\circ} \mathrm{C}$ (at a nominal P of $12 \mathrm{kbar}$ ). Pressures of $13 \pm 2$ kbar were obtained using the phengite-quartzwater method of Dubacq et al. (2010; see Online Resource 1, Fig. 1).

3. In the pre-Alpine marbles and meta-cherts (Cuney and Becca di Salé slices), the same method yields (maximum) pressures of about $17 \mathrm{kbar}$ for a nominal $\mathrm{T}$ of $500{ }^{\circ} \mathrm{C}$. 
ROISAN-CIGNANA SHEAR ZONE

Granitoid basement (AS-LU)

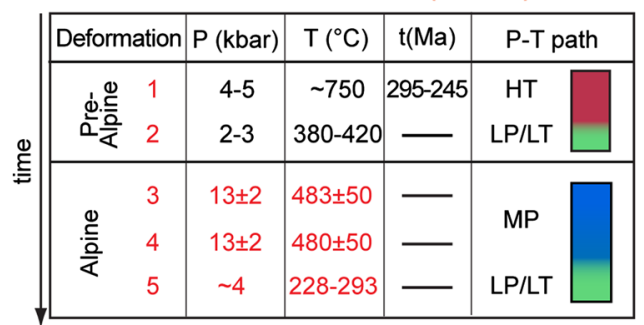

Cuney and Becca di Salé slices

\begin{tabular}{|c|c|c|c|c|c|}
\hline \multirow{2}{*}{\multicolumn{2}{|c|}{ Deformation }} & $P$ (kbar) & $\mathrm{T}\left({ }^{\circ} \mathrm{C}\right)$ & $\mathrm{t}(\mathrm{Ma})$ & P-T path \\
\hline & & $4-5$ & $\sim 740$ & $\begin{array}{c}297 \pm 6 \\
\sim 265\end{array}$ & HT \\
\hline \multirow{3}{*}{$\frac{\text { 든 }}{\frac{\circ}{2}}$} & 3 & $\sim 17$ & $\sim 500$ & & \multirow{2}{*}{ MP } \\
\hline & 4 & $\sim 17$ & $\sim 500$ & & \\
\hline & 5 & $\sim 4$ & $255-353$ & & LP/LT \\
\hline
\end{tabular}

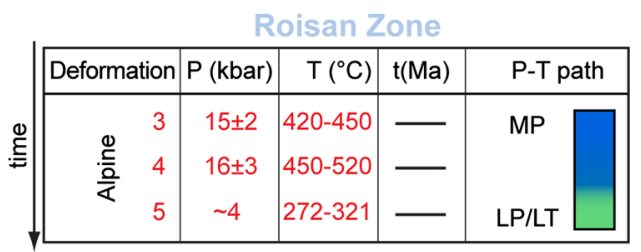

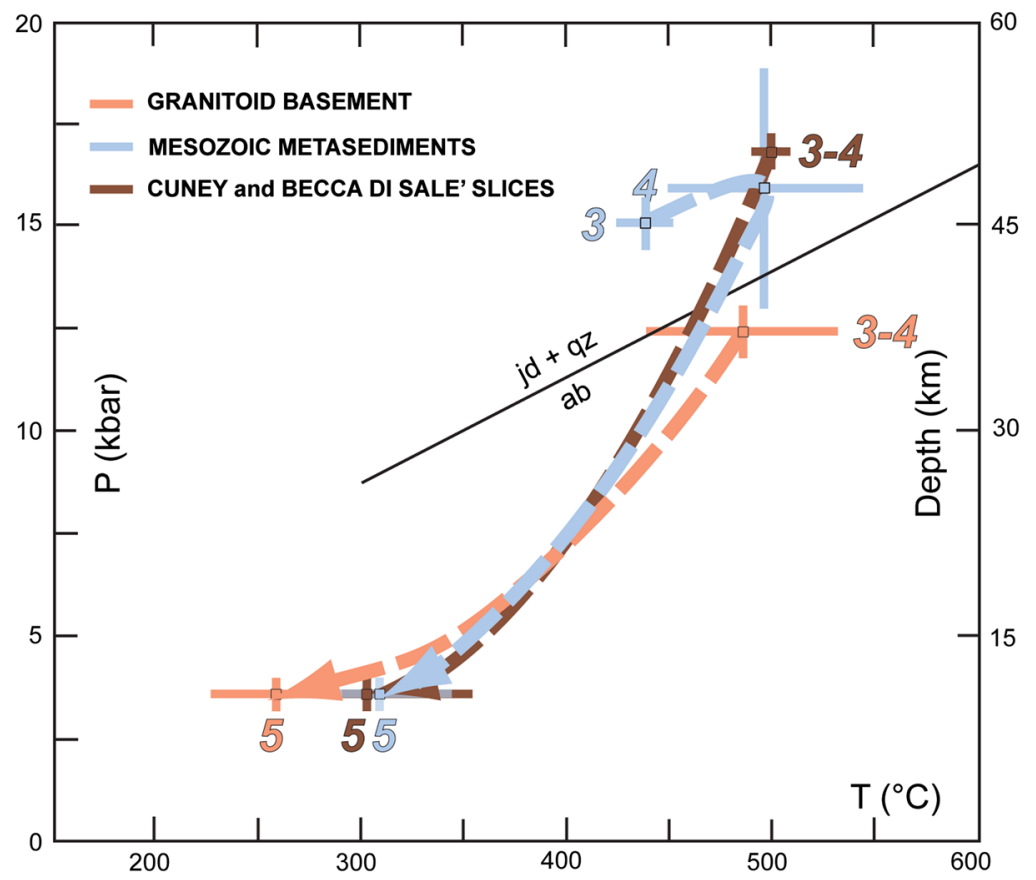

Fig. 10 Summary of P-T-d-t table for the studied tectonic slices (Arolla series, Lower Unit of the Mont Mary nappe, Roisan Zone, pre-Alpine meta-sediments, all belonging to the DBTS) involved in the RCSZ. New data obtained from this study are in red. Literature data are reported in black (Roda and Zucali, 2008; Manzotti et al., 2012). A coloured column indicates the metamorphic conditions that existed during the different stages of the evolution (HT high

For stage 5, the chlorite-quartz-water method of Vidal et al. (2005, 2006) yields temperatures ranging from 272-321 ${ }^{\circ} \mathrm{C}$ in Qz-micaschist (Roisan Zone), $228-293{ }^{\circ} \mathrm{C}$ in blue amphibole bearing orthogneiss (Arolla Series of the Dent Blanche s.s. nappe and Lower Unit of the Mont Mary nappe), $255-277{ }^{\circ} \mathrm{C}$ in meta-chert, and $259-353{ }^{\circ} \mathrm{C}$ in impure marble (Cuney and Becca di Salé slices) (Table 3 and Online Resource 1, Fig. 2). Temperature and $\mathrm{X}_{\mathrm{Fe}}^{3+}$ were estimated for a fixed pressure of $4 \mathrm{kbar}$ and assuming an aqueous fluid with a $\left(\mathrm{H}_{2} \mathrm{O}\right)=1$. temperature-amphibolite/granulite facies, BSF blueschist facies, $G S F$ greenschist facies). The graph shows the Alpine $\mathrm{P}-\mathrm{T}$ evolution for the basement units (Arolla Series and Lower Unit of the Mont Mary nappe), the Roisan Zone and the Cuney and Becca di Sale slices, along the RCSZ. The $\mathrm{Ab}=\mathrm{Jd}+\mathrm{Qz}$ equilibrium is calculated according to Holland (1980)

To sum up, the samples studied display a polyphase Alpine metamorphism (Fig. 10). Peak P-T conditions were attained during stages 3 and 4 , at a maximum $\mathrm{T}$ near $520{ }^{\circ} \mathrm{C}$ and a $\mathrm{P}$ at around $16 \mathrm{kbar}$. Pressures estimated using phengite thermobarometry (Dubacq et al. 2010) are maximum values. As petrographic observation indicates that albite was stable during stages 3 and 4, pressures probably were slightly lower, on the order of $13 \mathrm{kbar}$, but it is not possible to give precise pressure values. Decompression is evident already in stage 5 assemblages, at slightly lower temperatures. 


\section{Tectonic history of the Dent Blanche Tectonic System}

The meso- and micro-scale data presented above allow for a reconstruction of the structural and metamorphic history of the RCSZ. In the following sections, the new results are integrated and combined with previous interpretations, in order to elucidate the geodynamic evolution of the whole DBTS, within which the RCSZ is central importance.

\subsection{Pre-Alpine evolution (Permian)}

The high temperature metamorphism discovered in the Cuney and Becca di Salé pre-Alpine meta-sediments ( T $\sim 740{ }^{\circ} \mathrm{C}, \mathrm{P} 4-5 \mathrm{kbar}$, Manzotti et al. 2012) suggests that these rocks represent small pre-Alpine tectonic slices that may derive from the Upper Unit of the Mont Mary nappe. The Permian metamorphic age strongly suggests that these rocks were exposed to extension-related heating in Permian times, although the exact initial location of these units with respect to DBTS itself remains uncertain (Manzotti et al. 2012). Comparable high temperature metamorphic imprints have been described in the Valpelline Series of the DBTS (Manzotti and Zucali 2013), and they have been widely recorded in the pre-Alpine crust of the Alps, where they are interpreted as evidence of Permian-Triassic lithospheric thinning (Vavra et al. 1996; Hermann and Rubatto 2003; Marotta and Spalla 2007 and refs therein; Schuster and Stüwe 2008; Miller and Thöni 2009).

Permian magmatism is well known in the DBTS and in many parts of the Western Alps. It is characterized by mafic intrusives (Collon and Cervino gabbros: $250 \pm 5 \mathrm{Ma}, \mathrm{K} / \mathrm{Ar}$, Rb/Sr, cf. Dal Piaz et al. 1977; $284 \pm 1 \mathrm{Ma}, \mathrm{U} / \mathrm{Pb}$, cf. Monjoie et al. 2005), and by more evolved granitoids (Mucrone grandiorite: $293 \pm 1 \mathrm{Ma}$, $\mathrm{U} / \mathrm{Pb}$; Arolla granites: $289 \pm 2 \mathrm{Ma}, \mathrm{U} / \mathrm{Pb}$; Emilius granitoids: $293 \pm 3 \mathrm{Ma}, \mathrm{U} / \mathrm{Pb}$; protolith of the Etirol Levaz mylonitic gneiss: ca $265 \mathrm{Ma}, \mathrm{U} / \mathrm{Pb}$; cf. Paquette et al. 1989; Bussy et al. 1998; Beltrando et al. 2010b).

The units that actually constitute the DBTS (e.g. the Valpelline Series and the Arolla Series of the Dent Blanche s.s. nappe and the Lower and Upper Units of the Mont Mary nappe) experienced a different polyphase P-T history during Permian time (Gardien et al. 1994; Pennacchioni and Cesare 1997; Roda and Zucali 2008; Manzotti and Zucali 2013), with the highest metamorphic grade reached by the Valpelline Series of the Dent Blanche s.s. nappe (P$\mathrm{T}_{\max } 8$ kbar-860 ${ }^{\circ} \mathrm{C}$, Manzotti and Zucali 2013) and probably by the Upper Unit of the Mont Mary nappe. The differences in the Permian metamorphic grade suggest that, in Permian time, the Arolla Series (of the Dent Blanche s.s. nappe) and the Lower Unit (of the Mont Mary nappe) may correspond to middle-upper continental crust, whereas the
Valpelline Series (of the Dent Blanche s.s. nappe) and the Upper Unit (of the Mont Mary nappe) may represent lower continental crust (Gardien et al. 1994; Bonetto et al. 2010; Dal Piaz et al. 2010; Manzotti et al. 2012).

\subsection{Heterogeneous thinning of the lower crust (Permian or Jurassic?)}

In the DBTS, more precisely in the Upper Unit of the Mont Mary nappe, discrete zones of mylonites-ultramylonites, developed at the brittle-ductile transition and characterized by a NE-SW trending mineral stretching lineation, have been described and interpreted as evidence of the extensional regime (Pennacchioni and Cesare 1997). Although their age has not been established, these shear zones are thought to have developed in the lower crust, either during the Permian or the Jurassic.

\subsection{Passive margin evolution in the cover (Triassic-Jurassic)}

In the DBTS, the sedimentary sequences now forming the Mont Dolin Series (Hagen 1948; Weidmann and Zaninetti 1974) and the Roisan Zone (Diehl et al. 1952; Ciarapica et al. 2010) are remnants of the Mesozoic sedimentary cover that was deposited along the Adriatic passive margin. The Mont Dolin Series (Fig. 2) comprises Late Triassic to mid-Jurassic sediments (Hagen 1948; Weidmann and Zaninetti 1974; Ayrton et al. 1982), including mono- and polygenic breccias. The breccias correspond to syntectonic sediments that record the progressive erosion of the Triassic dolomites (monogenic breccias) and then of the Arolla basement (polygenic breccias). Thus, the MontDolin Series may have been deposited close to a normal fault that was active during the early Jurassic, and record the progressive unroofing of the Triassic and its underlying basement.

In the Roisan Zone, pervasive transposition of the primary sedimentary contacts precludes a reliable reconstruction of the original lithostratigraphy in most cases. Sedimentary facies and fossil contents can be compared to the Mont Dolin Series (Ciarapica et al. 2010). The two Mesozoic sequences differ in sedimentary facies because (1) quartzites of presumed Early Triassic age are not found in the Roisan Zone, and (2) some breccias do occur in the Triassic dolomites of the Roisan Zone (Ciarapica et al. 2010), while no equivalents of the monogenic and polygenic breccias have been found. This implies that the Mesozoic sequence was detached from its Permian and Early Triassic cover, and that Jurassic sediments are lacking or alternatively, the sediments of the Roisan Zone were deposited in a basinal setting, away from the active normal faults that segmented the 


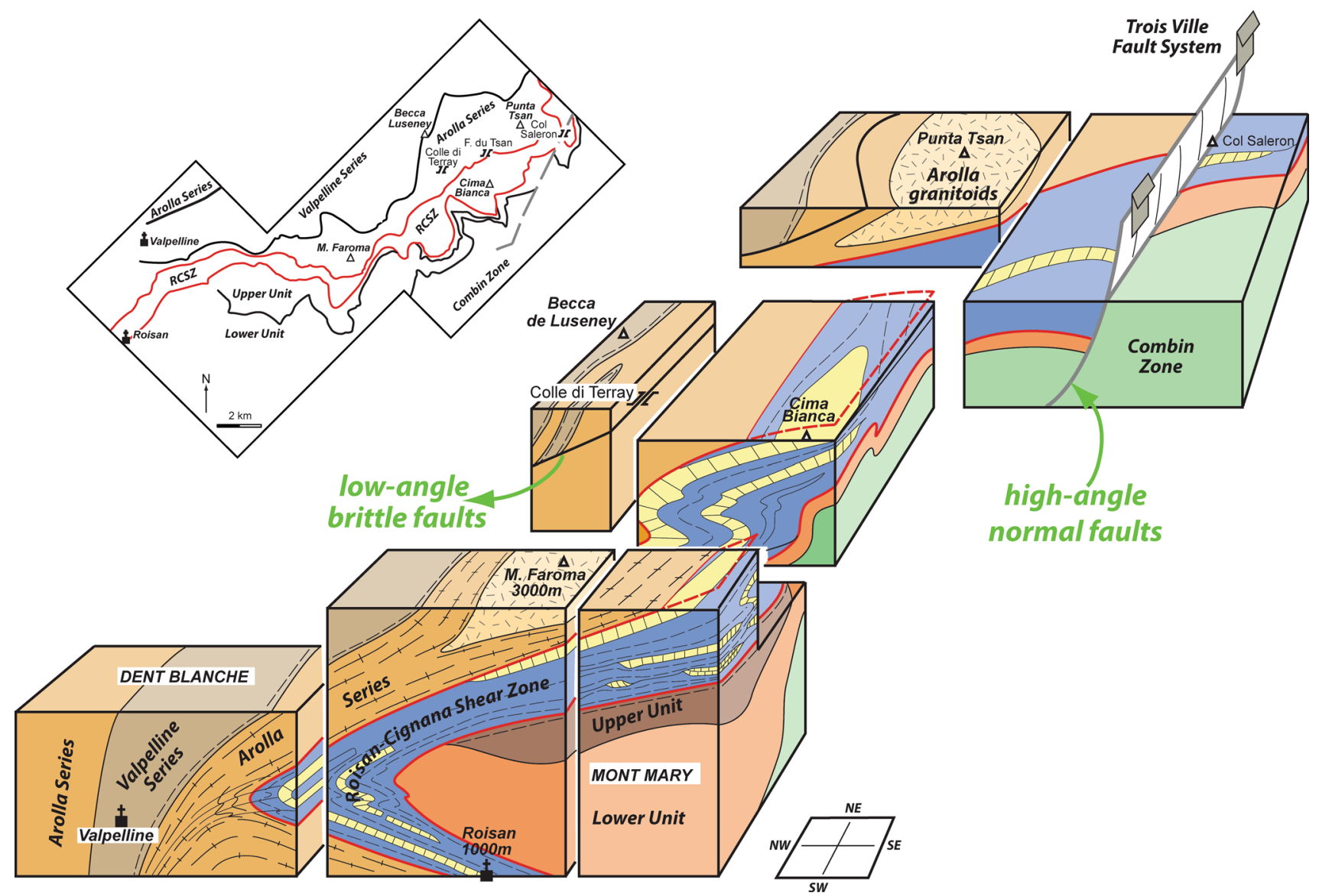

Fig. 11 Simplified 3-D model of the RCSZ showing the geometry and geology of the tectonic units and the location of the main brittle fault zones. The general colour scheme follows that shown in Fig. 2, except for the yellow horizons within the RCSZ (dolomite boudins and carbonate layers) and Permian granitoid domains in the Arolla Series (Punta Tsan, M. Faroma)
Adriatic palaeomargin. Finally, no meta-radiolarites of presumed Jurassic or Cretaceous age are present: Manzotti et al. (2012) have demonstrated that the candidates discovered by Ballèvre and Kiénast (1987) record HT assemblages of Permian age and thus they belong to another tectonic unit.

\subsection{Early Alpine (ductile) evolution (late Cretaceous-Eocene)}

Within the DBTS, the RCSZ defines the boundary between the Dent Blanche s.s. and the Mont Mary nappes. The present study reveals that this kilometric high-strain zone results from several Alpine (ductile) deformation phases (e.g. D3, D4), comprising two relatively high-P metamorphic and structural stages (stages 3 and 4). Stage 5 is a deformational event that occurred at greenschist facies conditions, associated with the folding of the RCSZ (Fig. 11). This polyphase evolution is responsible for the formation of the mylonitic S-L-type fabrics found within the RCSZ. Metamorphic and structural evidence suggests that a tectonic incorporation of the Cuney and Becca di Salé slices in the polydeformed basement of the Arolla Series (Dent Blanche s.s. nappe) and of the Lower Unit (Mont Mary nappe) occurred prior to or during stage 3, at relatively high pressure conditions $(\sim 13 \pm 2$ kbar).

Tectonic slices of the Roisan Zone were deformed together with the basement of the Arolla Series of the Dent Blanche s.s. nappe and basement of the Lower Unit of the Mont Mary nappe during stages 3 and 4. At the basementcover contact, high pressure assemblages clearly mark a composite S3 + S4 foliation. Moreover, structural evidence indicates that basement and cover were deformed together during the D3 and D4 stages. Therefore, the incorporation of the tectonic slices of the Roisan Zone in the Arolla Series-Lower Unit basement probably occurred during stage 3. This implies that the tectonic intermingling between the basement of the Arolla Series (Dent Blanche s.s. nappe) and of the Lower Unit (Mont Mary nappe) and the Roisan Zone already occurred during the subduction process, when the $\mathrm{km}$-scale ductile RCSZ started to develop. 


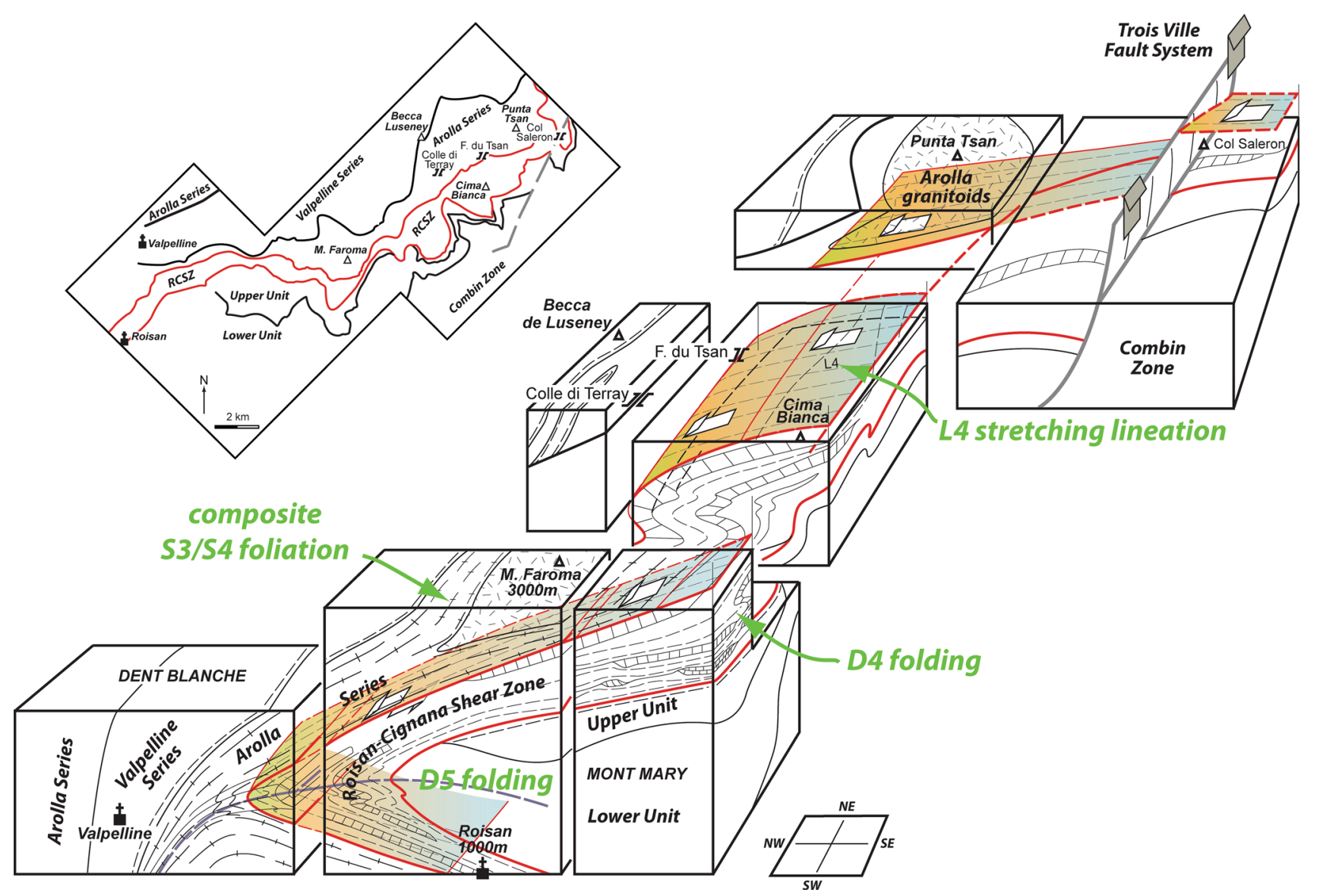

Fig. 12 Simplified 3-D model of the structural relations arising from ductile deformation stages D3, D4 and D5, in and around the RCSZ. The large scale fold visible in the Becca di Roisan-Rachaud area (nice panorama from Gignod village on the right side of the Buthier valley) is the result of stage 5. As suggested by kinematic markers (i.e. shear

Stages 3 and 4 thus reflect the subduction process during which a nappe emplacement phase occurred under blueschist facies conditions, producing the shearing of the Mesozoic Roisan Zone cover (resulting in its folding and boudinage) and the imbrication of the basement and cover slices (Fig. 11). During stage 4, a prominent NW-SE stretching lineation L4 developed; it is displayed by most of the rocks along the RCSZ, with the exception of the Triassic dolomites. Kinematic indicators related to L4 reflect a topto-NW sense of movement during stage 4 (Fig. 12).

Following the subduction phase (stages 3 and 4), this package of rocks was exhumed to shallower crustal levels, where greenschist facies assemblages developed (stage 5) at the expense of the blueschist assemblages. A new folding phase of the RCSZ evolved at greenschist facies and produced large scale folds (hundreds of metres in amplitude; Fig. 11) and moderate to pervasive crenulation or chevron folding.

The polyphase Alpine deformation and metamorphism are heterogeneously recorded in the basement and cover of bands and dolomite clasts in Jurassic sediments), a consistent top-toNW sense of transport characterizes the composite S3-S4 foliation in the the RCSZ. The shearing, the folding and the associated transposition of the Roisan Zone are the result of stage 4

the DBTS. During Alpine orogeny, large volumes of continental crust were left undeformed in the DBTS, with preAlpine features best preserved in the Valpelline and in the Arolla Series of the Dent Blanche s.s. nappe (e.g. Mont Morion granite, Becca d'Epicoune, Mont Collon and Cervino gabbros Fig. 2, and in the M. Faroma and Punta Tsan lenses in Fig. 11). Regional-scale Alpine ductile shear zones, comparable with the RCSZ, have been recognized along the Arolla-Valpelline boundaries in the Dent Blanche s.s. nappe (Diehl et al. 1952; Pennacchioni and Guermani 1993), as well as within the Arolla and Valpelline Series (Roda and Zucali 2011). These shear zones represent the oldest Alpine structures recognized in the DBTS; they were folded by subsequent deformational phases.

The mylonites at the Arolla-Valpelline contact in the Dent Blanche s.s. nappe display consistent kinematics with a top to the NW sense of shear (kinematic indicators: quartz shape fabric, shear bands, mica fish, S-C fabrics; (Pennacchioni and Guermani 1993), thus indicating a 
displacement of the Valpelline Series to the NW relative to the underlying Arolla Series. Blueschist facies conditions (e.g. sodic amphibole, aegirine-augite, garnet and phengite) prevailed during this deformation. One may speculate that the Arolla-Valpelline mylonitic contact may well have reworked previous (pre-Alpine) structures, e.g. extensional faults of Jurassic age. However, no definite proof has yet been found that the observed mylonites at the ValpellineArolla Series boundary did rework Jurassic cataclasites or mylonites.

In the DBTS, the Alpine polyphase evolution developed under blueschist to greenschist facies conditions (Diehl et al. 1952; Kiénast and Nicot 1971; Nicot 1977; Canepa et al. 1990; Pennacchioni and Guermani 1993; Roda and Zucali 2008). The age of the blueschist facies metamorphism remains poorly constrained (Hunziker 1974). However, in the Pillonet klippe, concordant $\mathrm{Rb}-\mathrm{Sr}$ (75 Ma) and ${ }^{40} \mathrm{Ar}-{ }^{39} \mathrm{Ar}$ (75-73 Ma) plateau ages on similar phengitic mica coexisting with glaucophane-crossite from Arolla-type meta-granitoids indicate a Late Cretaceous age for the Alpine high-pressure phase (Cortiana et al. 1998). This metamorphism may have overlapped in time with one of the phases of the Late Cretaceous eclogitic metamorphism observed farther to the south (in the Sesia Zone: Rubatto et al. 2011; Regis et al. 2014).

The age of the greenschist-facies stage is not constrained by isotopic data in the DBTS. However, for geometrical reasons it is assumed to have the same age as in the external part of the Sesia Zone, where the Gneiss Minuti Complex are cut by undeformed calc-alkaline to shoshonitic dykes associated with the Biella intrusion; these dikes yield intrusion ages of 32-30 Ma (Kapferer et al. 2012). Therefore, the greenschist-facies stage in the DBTS must be older than $32 \mathrm{Ma}$, probably earliest Oligocene.

\subsection{Late Alpine (brittle) evolution (Oligocene-Recent)}

Post-nappe brittle deformation is evident along the RCSZ as well as in the DBTS. Two types of faults have been recognized:

1. Low-angle faults (with cataclasite layers of up to $1 \mathrm{~m}$ ) cut across the previous ductile structures, including folds that deform the contact between the Arolla and the Valpelline Series of the Dent Blanche s.s. nappe (Fig. 4). The best example of this type of fault has been found north of the Cuney Santuario (Fig. 4) and of the Colle di Terray (Figs. 11, 12). This fault gently dips to the northwest, and shear criteria indicate a top-to-SW displacement. In its present attitude, this fault displays a normal sense of shear. However, great care should be taken in interpreting this conclusion, as the entire DBTS may represent a large-scale synform, of the same age as the Vanzone fold. If so, unfolding the gently dipping brittle fault would represent a folded reverse fault rather than a normal fault, i.e. may represent the latest contractional phase in this part of the Alps. Because the age of the Vanzone fold is ca. 25-20 Ma (Steck and Hunziker 1994; Keller et al. 2005; Steck et al. 2013), the low-angle brittle faults are assumed to be slightly older (ca. $30 \mathrm{Ma}$, early Oligocene).

2. In the area studied, the Trois Villes Fault System represents the major extensional fault system of the internal north-western Alps, offsetting the flat-lying boundary between the Austroalpine basement and Piedmont calcschists by ca. $1 \mathrm{~km}$ (Bistacchi and Massironi 2000; Bistacchi et al. 2009; Dal Piaz et al. 2010; see Figs. 11, 12). The main fault (Trois-Villes) cuts across the Mont Mary-Combin Zone boundary and is characterized by a thick cataclastic horizon (containing pseudotachylites), dipping $45^{\circ}-50^{\circ}$ towards NW (Bistacchi and Massironi 2000; Bistacchi et al. 2009; Dal Piaz et al. 2010). To the north (Fig. 4), a high angle fault also cuts across the nappe pile (from Col Saleron to Colle nord del Monte Meabé), with a downthrow of the western block. The horizontal component of displacement in map view results from the slight dip to the $\mathrm{N}$ of the earlier thrust boundaries and does not require a transcurrent movement along the fault. Again, the age of this fault system is not precisely known, but it is either Oligocene or Miocene (Bistacchi and Massironi 2000; Bistacchi et al. 2009; Dal Piaz et al. 2010).

In the Aosta Valley, post-nappe brittle faulting is mainly associated with the E-W trending Aosta-Ranzola Fault ( 18-25 Ma; Balestrieri et al. 1999; Fügenschuh et al. 1999; Bernet et al. 2001; Malusà et al. 2005; Bistacchi et al. 2011), with a 2-3 km downthrow of the northern block. The NE-SW trending faults (i.e. the Trois Villes Fault system), with minor offset compared to the Aosta-Ranzola Fault, are considered to be of the same age as the Aosta-Ranzola Fault (Bistacchi et al. 2001; Dal Piaz et al. 2010).

\section{Conclusions}

The Dent Blanche Tectonic System (DBTS) is a large composite thrust sheet, derived from the fragmented Adriatic continental margin. The Roisan-Cignana Shear Zone (RCSZ) is a kilometric Alpine shear zone that separates the DBTS into two main subunits, the Dent Blanche s.s. and the Mont Mary nappes. Field evidence allows one to recognize the imbrication and shearing of basement (pre-Alpine) and cover (Mesozoic) slices within the RCSZ. This high-strain zone, characterized by 
consistent kinematics reflecting top-to-NW sense of shear, is the result of superimposed Alpine deformational stages, which initiated under blueschist facies (maximum $520{ }^{\circ} \mathrm{C}$, 16 kbar; D3 and D4 stages) and ended under greenschist facies conditions (D5 stage). The latter stage involves major folding of the previous nappe stack, associated with an extensive crenulation cleavage. The post-nappe evolution, occurring at shallower levels, includes the development of low-angle brittle faults, followed by the large-scale folding (Vanzone phase) and finally extensional brittle faults.

The geometric and kinematic evolution of the RCSZ is tentatively placed in a larger context. During subduction, several sheets of crustal material were stacked and separated by shear zones reworking their Mesozoic cover. The RCSZ represents one of these shear zones. The blueschist facies stages (D3-D4) are related to burial at great depth in the subduction zone, during which crustal slices (namely the Dent Blanche on top of the Mont Mary) of the Adriatic crust were stacked together. The greenschist facies phase (D5) reflects a major episode of folding of the previous nappe stack, possibly associated with its emplacement to its present position above the ophiolitic complexes (ZermattSaas and Combin Zones). In summary, the RCSZ shows that fragments of continental crust had been torn off the passive continental margin prior to continental collision, thus recording the entire history of the orogenic cycle. A full discussion of the tectonic evolution of the DBTS and the related Sesia Zone, integrating the new data presented above with previous research, is presented in a sequel paper (Manzotti et al. 2014).

Acknowledgments This work was financially supported by the Swiss National Science Foundation (Project 200020-126946). We gratefully acknowledge field assistance by Daniele Regis, and Pierre Lanari's help with Chl-Wm thermobarometry. We would like also to warmly thank Giorgio Vittorio Dal Piaz for providing us with the first proofs of the Cervino geological map, for discussions in Cogne and Cervinia and for visiting us in the field in the company of L. Passeri. Many thanks are due to the three reviewers, Mark Handy and Geoffroy Mohn, and especially to Associate Editor Stefan Schmid for his detailed and useful suggestions. Last but not least, the editorial work of A. G. Milnes has been greatly appreciated.

\section{References}

Allaz, J., Engi, M., Berger, A., \& Villa, I. M. (2011). The effects of retrograde reactions and of diffusion on ${ }^{39} \mathrm{Ar}-{ }^{40} \mathrm{Ar}$ ages of micas. Journal of Petrology, 52, 691-716.

Argand, E. (1906). Sur la tectonique du Massif de la Dent Blanche. Comptes Rendus de l'Académie des Sciences Paris, 142, $527-530$.

Argand, E. (1908). Carte géologique du Massif de la Dent Blanche (moitié septentrionale), 1:50 000, carte spéciale 52. Materiaux pour la carte géologique de la Suisse.
Argand, E. (1911). L'exploration géologique des Alpes Pennines Centrales. Bulletin des Laboratoires de Géologie de l'Université de Lausanne, 14.

Ayrton, S., Bugnon, C., Haarpainter, T., Weidmann, M., \& Frank, E. (1982). Géologie du front de la nappe de la Dent Blanche dans la région des Monts-Dolins, Valais. Eclogae Geologicae Helvetiae, 75, 269-286.

Baldelli, C., Dal Piaz, G. V., \& Polino, R. (1983). Le quarziti a manganese e cromo di Varenche-St. Barthélémy, una sequenza di copertura oceanica della falda piemontese. Ofioliti, 8, 207-221.

Balestrieri, M. L., Bigazzi, G., Bistacchi, A., Martin, S., Massironi, M., Polino, R. \& Zattin, M. (1999). Investigation on brittle tectonics in a collisional nappe-stack (NW Alps) using fission track analysis. In Martin S. and Polino R. (Eds), Fission Track Analysis: Theory and Applications (51/2, pp. 438-440). Memorie di Scienze Geologiche di Padova.

Baletti, L., Zanoni, D., Spalla, M. I., \& Gosso, G. (2012). Structural and petrographic map of the Sassa gabbro complex (Dent Blanche nappe, Austroalpine tectonic system, Western Alps, Italy)—1: 2500. Journal of Maps, 8, 413-430.

Ballèvre, M., \& Kiénast, J. R. (1987). Découverte et signification de paragenèses à grenat-amphibole bluè dans la couverture mesozoique de la nappe de la Dent-Blanche (Alpes Occidentales). Comptes Rendus de l'Académie des Sciences Paris, 305, 43-46.

Ballèvre, M., Kiénast, J. R., \& Vuichard, J. P. (1986). La "nappe de la Dent-Blanche" (Alpes occidentales): Deux unités austroalpines indépendantes. Eclogae Geologicae Helvetiae, 79, 57-74.

Ballèvre, M., \& Merle, O. (1993). The Combin Fault: Compressional reactivation of a Late Cretaceous-Early Tertiary detachment fault in the Western Alps. Schweizerische Mineralogische und Petrographische Mitteilungen, 73, 205-227.

Barnicoat, A. C., \& Fry, N. (1986). High-pressure metamorphism of the Zermatt-Saas ophiolite zone, Switzerland. Journal of the Geological Society of London, 143, 607-618.

Barnicoat, A. C., Rex, D. C., Guise, P. G., \& Cliff, R. A. (1995). The timing and nature of greenschist facies deformation and metamorphism in the upper Pennine Alps. Tectonics, 14, 279-293.

Battiston, P., Benciolini, L., Dal Piaz, G. V., De Vecchi, G., Marchi, G., Polino, R., et al. (1987). Geologia di una traversa del Gran Paradiso alla zona Sesia-Lanzo in alta Val Soana, Piemonte. Memorie della Società Geologica Italiana, 29, 209-232.

Bearth, P. (1967). Die Ophiolite der Zone von Zermatt-Saas Fee. Beiträge zur Geologischen Karte der Scweiz (NF), 132.

Bearth, P., Dal Piaz, G. V., Elter, G., Gosso, G., \& Martinotti, G. (1980). Il lembo di ricoprimento del Monte Emilius, Dent Blanche s.l. Atti della Reale Accademia delle scienze di Torino, 114, 226-240.

Beltrando, M., Compagnoni, R., \& Lombardo, B. (2010a). (Ultra) High-pressure metamorphism and orogenesis: An Alpine perspective. Gondwana Research, 18, 147-166.

Beltrando, M., Rubatto, D., \& Manatschal, G. (2010b). From passive margins to orogens: The link between ocean-continent transition zones and (ultra)high-pressure metamorphism. Geology, 38, $559-562$

Bernet, M., Zattin, M., Garver, J. I., Brandon, M. T. \& J.A., V. (2001). Steady-state exhumation of the European Alps. Geology, 29, 35-38.

Beyssac, O., Goffé, B., Chopin, C., \& Rouzaud, J. N. (2002). Raman spectra of carbonaceous material in metasediments: A new geothermometer. Journal of Metamorphic Geology, 20, 859-871.

Beyssac, O., Goffé, B., Petitet, J. P., Froigneux, E., Moreau, M., \& Rouzaud, J. N. (2003). On the characterization of disordered and heterogeneous carbonaceous materials using Raman spectroscopy. Spectrochimica Acta A, 59, 2267-2276.

Bistacchi, A., Dal Piaz, G. V., Massironi, M., Zattin, M., \& Balestrieri, M. L. (2001). The Aosta-Ranzola extensional fault 
system and Oligocene-Present evolution of the north-western Alpine nappe stack. International Journal of Earth Sciences, 90, 654-667.

Bistacchi, A., Dal Piaz, G. V., Massironi, M., Zattin, M., \& Balestrieri, M. L. (2011). The Aosta-Ranzola extensional fault system and Oligocene-Present evolution of the Austroalpine Penninic wedge in the northwestern Alps. International Journal of Earth Sciences, 90, 654-667.

Bistacchi, A., \& Massironi, M. (2000). Post-nappe brittle tectonics and kinematic evolution of the north-western Alps: An integrated approach. Tectonophysics, 327, 267-292.

Bistacchi, A., Pennacchioni, G., Gatta, G. D., \& Grizzetti, R. (2009). Seismic slip at the base of the seismogenic crust along the exhumed extensional Oligocene Trois Villes Fault (Western Italian Alps). Geophysical Research Abstracts, 11, 11855.

Bonetto, F., Dal Piaz, G. V., Pennacchioni, G., Tartarotti, P. \& Carraro, F. (2010). Carta Geologica d'Italia alla scala 1:50 000, Foglio 091, Chatillon, Servizio Geologico d'Italia.

Bousquet, R., Engi, M., Gosso, G., Oberhänsli, R., Berger, A., Spalla, M. I., et al. (2004). Explanatory notes to the map: Metamorphic structure of the Alps. Transition from the Western to the Central Alps. Österreichische Mineralogische Gesellschaft, 149, 145-156.

Bucher, K., Dal Piaz, G. V., Oberhänsli, R., Gouffon, Y., Martinotti, G., \& Polino, R. (2003). Blatt 1347 Matterhorn-Geologischer Atlas der Schweiz 1:25000, Karte 107. Bern: Bundesamt für Wasser und Geologie.

Bucher, K., Fazis, Y., De Capitani, C., \& Grapes, R. (2005). Blueschists, eclogites, and decompression assemblages of the Zermatt-Saas ophiolite: High-pressure metamorphism of subducted Tethys lithosphere. American Mineralogist, 90, 821-835.

Bussy, F., Venturini, G., Hunziker, J. C., \& Martinotti, G. (1998). $\mathrm{U}-\mathrm{Pb}$ ages of magmatic rocks of the Western Austroalpine DentBlanche-Sesia Unit. Schweizerische Mineralogische und Petrographische Mitteilungen, 78, 163-168.

Caby, R. (1981). Le Mésozoique de la zone du Combin en Val d'Aoste (Alpes graies): Imbrications tectoniques entre séries issues des domaines pennique, austroalpin et océanique. Géologie Alpine, 57, 5-13.

Canepa, A., Castelletto, M., Cesare, B., Martin, S., \& Zaggia, L. (1990). The Austroalpine Mont Mary nappe (Italian Western Alps). Memorie di Scienze Geologiche, 42, 1-17.

Cartwright, I., \& Barnicoat, A. C. (2002). Petrology, geochronology, and tectonics of shear zones in the Zermatt-Saas and Combin zones of the Western Alps. Journal of Metamorphic Geology, 20, 263-281.

Ciarapica, G., Dal Piaz, G. V., \& Passeri, L. (2010). Late Triassic microfossils in the Roisan zone, Austroalpine Dent BlancheMont Mary nappe system, NW-Alps. Rendiconti Online Società Geologica Italiana, 11, 261.

Compagnoni, R. (1977). The Sesia-Lanzo Zone: High pressure-low temperature metamorphism in the Austroalpine continental margin. Rendiconti della Società Italiana di Mineralogia e Petrologia, 33, 335-378.

Compagnoni, R., Dal Piaz, G. V., Hunziker, J. C., Gosso, G., Lombardo, B., \& Williams, P. F. (1977). The Sesia-Lanzo zone, a slice of continental crust with Alpine high pressure-low temperature assemblages in the Western Italian Alps. Rendiconti della Società Italiana di Mineralogia e Petrologia, 33, 281-334.

Cortiana, G., Dal Piaz, G. V., Del Moro, A., Hunziker, J. C., \& Martin, S. (1998). ${ }^{40} \mathrm{Ar}-{ }^{39} \mathrm{Ar}$ and $\mathrm{Rb}-\mathrm{Sr}$ dating of the Pillonet klippe and Sesia-Lanzo basal slice in the Ayas valley and evolution of the Austroalpine-Piedmont nappe stack. Memorie di Scienze Geologiche, 50, 177-194.

Dal Piaz, G. V. (1965). La formazione mesozoica dei calcescisti con pietre verdi fra la Valsesia e la Valtournanche ed i suoi rapporti strutturali con il ricoprimento del Monte Rosa e con la Zona
Sesia-Lanzo. Bollettino della Società Geologica Italiana, 84, 67-104.

Dal Piaz, G. V. (1976). Il lembo di ricoprimento del Pillonet (falda della Dent Blanche nelle Alpi Occidentali) (pp. 1-60). XXXI: Memorie di Scienze Geologiche.

Dal Piaz, G. V. (1988). Revised setting of the Piedmont zone in the northern Aosta valley, Western Alps. Ofioliti, 13, 157-162.

Dal Piaz, G. V. (1997). Geology of the Matterhorn and surroundings. Quaderni di Geodinamica Alpina e Quaternaria, 4, 36-37.

Dal Piaz, G. V. (1999). The Austroalpine-Piedmont nappe stack and the puzzle of Alpine Tethys. Memorie di Scienze Geologiche, 51, $155-176$.

Dal Piaz, G. V., Cortiana, G., Del Moro, A., Martin, S., Pennacchioni, G., \& Tartarotti, P. (2001). Tertiary age and paleostructural inferences of the eclogitic imprint in the Austroalpine outliers and Zermatt-Saas ophiolite, western Alps. International Journal of Earth Sciences, 90, 668-684.

Dal Piaz, G. V., De Vecchi, G., \& Hunziker, J. C. (1977). The Austroalpine layered gabbros of the Matterhorn and Mt. CollonDents de Bertol. Schweizerische Mineralogische und Petrographische Mitteilungen, 57, 59-88.

Dal Piaz, G. V., Di Battistini, G., Kiénast, J. R., \& Venturelli, G. (1979a). Manganiferous quartzitic schists of the Piemonte ophiolite nappe (pp. 4-24). XXXII: Memorie di Scienze Geologiche.

Dal Piaz, G. V., \& Ernst, W. G. (1978). Areal geology and petrology of eclogites and associated metabasites of the Piemonte Ophiolite Nappe, Breuil-St. Jacques area, Italian Western Alps. Tectonophysics, 5, 99-126.

Dal Piaz, G. V., Gianotti, F., Monopoli, B., Pennacchioni, G., Tartarotti, P., \& Schiavo, A. (2010). Note illustrative della Carta Geologica d'Italia alla scala 1:50.000, Foglio 091 Chatillon. Servizio Geologico d'Italia, Foglio, 091, 5-152.

Dal Piaz, G. V., Gosso, G., \& Martinotti, G. (1971). La II Zona Diorito-Kinzigitica tra la Valsesia e la valle d'Ayas. Memorie della Società Geologica Italiana, 10, 257-276.

Dal Piaz, G. V., Hunziker, J. C., \& Martinotti, G. (1972). La zona Sesia-Lanzo e l'evoluzione tettonico-metamorfica delle Alpi nordoccidentali interne. Memorie della Società Geologica Italiana, 11, 433-466.

Dal Piaz, G. V., Lombardo, B., \& Gosso, G. (1983). Metamorphic evolution of the Mt. Emilius klippe, Dent Blanche nappe, Western Alps. American Journal of Science, 283A, 438-458.

Dal Piaz, G. V., \& Nervo, R. (1971). Il lembo di ricoprimento del Glacier-Rafray (Dent Blanche s.1.). Bollettino della Società Geologica Italiana, 90, 401-414.

Dal Piaz, G. V., Nervo, R. \& Polino, R. (1979b). Carta geologica del lembo del Glacier-Rafray (Dent Blanche s.1.) e note illustrative-1: 12 500. Torino: Centro Nazionale delle Richerche, Centro di studio sui problemi dell'orogeno delle Alpi Occidentali, 2, 14 pp.

De Giusti, F., Dal Piaz, G. V., \& Massironi, M. (2003). Carta Geotettonica della Valle d'Aosta-1: 150000 e note illustrative. Memorie Scienze Geologiche, 55, 129-149.

De Leo, S., Biino, G., \& Compagnoni, R. (1987). Riequilibrazioni metamorfiche alpine nella serie di Valpelline e di Arolla a Nord di Bionaz (Valpelline-Aosta). Rendiconti della Società Italiana di Mineralogia e Petrologia, 42, 181-182.

Diehl, E. A., Masson, R., \& Stutz, A. H. (1952). Contributo alla conoscenza del ricoprimento della Dent Blanche. Memorie degli Istituti di Geologia e Mineralogia dell'Università di Padova, 17, $1-52$.

Dubacq, B., Vidal, O., \& De-Andrade, V. (2010). Dehydration of dioctahedral aluminous phyllosilicates: Thermodynamic modelling and implication for thermobarometric estimates. Contributions to Mineralogy and Petrology, 159, 159-174. 
Elter, G. (1960). La zona pennidica dell'alta e media Valle d'Aosta e le unità limitrofe. Memorie degli Istituti di Geologia e Mineralogia dell'Università di Padova, 23, 113.

Elter, G. (1971). Schistes lustrés et ophiolites de la zone piémontaise entre Orco et Doire Baltée (Alpes Graies). Hypothèses sur l'origine des ophiolites. Géologie Alpine, 47, 147-169.

Elter, G. (1987). Carte Géologique de la Vallée d'Aoste—1: 100000. Firenze: Centro Nazionale delle Ricerche, Centro di studio sui problemi dell'orogeno delle Alpi Occidentali.

Ernst, W. G., Tsujimori, T., Zhang, R., \& Liou, J. G. (2007). PermoTriassic collision, subduction-zone metamorphism and tectonic exhumation along the East Asian continental margin. Annual Review of Earth and Planetary Science, 35, 73-110.

Finger, W. (1978). Die Zone von Samaden (Unterostalpine Decken, Graubünden) und ihre Jurassichen Brekzien. Ph.D. dissertation, ETH, Zurich.

Fügenschuh, B., Loprieno, A., Ceriani, S., \& Schmid, S. M. (1999). Structural analysis of the Subbriançonnais and Valais units in the area of Moutiers (Savoy, Western Alps): Paleogeographic and tectonic consequences. International Journal of Earth Sciences, 88, 201-218.

Gardien, V., Reusser, E., \& Marquer, D. (1994). Pre-Alpine metamorphic evolution of the gneisses from Valpelline series (Western Alps, Italy). Schweizerische Mineralogische und Petrographische Mitteilungen, 74, 489-502.

Gosso, G., Dal Piaz, G. V., Piovano, V., \& Polino, R. (1979). High pressure emplacement of Early-Alpine nappes, postnappe deformations and structural levels (Internal Northwestern Alps) (pp. 5-15). XXXII: Memorie degli Istituti di Geologia e Mineralogia dell'Università di Padova.

Gouffon, Y. (1993). Géologie de la "nappe" du Grand St-Bernard entre la Doire Baltée et la frontière suisse (Vallée d'AosteItalie). Ph.D. dissertation, Université de Lausanne, Lausanne.

Groppo, C., Beltrando, M., \& Compagnoni, R. (2009). The P-T path of the ultra-high pressure Lago di Cignana and adjoining highpressure meta-ophiolitic units: Insights into the evolution of the subducting Tethyan slab. Journal of Metamorphic Geology, 27, 207-231.

Hagen, T. (1948). Geologie des Mont Dolin und des Nord randes der Dent Blanche-Decke zwischen Mont Blanc de Cheilon und Ferpècle (Wallis)—1: 5000. Spezialkarte n. 119. Bern: Beitrag Geologische Karte Schweiz.

Handy, M. R., Schmid, S. M., Bousquet, R., Kissling, E., \& Bernoulli, D. (2010). Reconciling plate-tectonic reconstructions of Alpie Tethys with the geological-geophysical record of spreading and subduction in the Alps. Earth Science Reviews, 102, 121-168.

Hermann, J., \& Rubatto, D. (2003). Relating zircon and monazite domains to garnet growth zones: Age and duration of granulite facies metamorphism in the Val Malenco lower crust. Journal of Metamorphic Geology, 21, 833-852.

Holland, T. J. B. (1980). The reaction albite $=$ jadeite + quartz determined experimentally in the range $600-1200^{\circ} \mathrm{C}$. American Mineralogist, 65, 129-134.

Hunziker, J. C. (1974). Rb-Sr and K-Ar determination and the Alpine tectonic history of the Western Alps. Memorie degli Istituti di Geologia e Mineralogia dell'Università di Padova, 31, 1-54.

Kapferer, N., Mercolli, I., Berger, A., Ovtcharova, M., \& Fügenschuh, B. (2012). Dating emplacement and evolution of the orogenic magmatism in the internal Western Alps: 2. The Biella Volcanic Suite. Swiss Journal of Geosciences, 105, 67-84.

Keller, L. M., Hess, M., Fügenschuh, B., \& Schmid, S. M. (2005). Structural and metamorphic evolution of the Camughera-Moncucco, Antrona and Monte Rosa units southwest of the Simplon line, Western Alps. Eclogae Geologicae Helvetiae, 98, 19-49.

Kiénast, J. R. (1983). Le métamorphisme de haute pression et basse température (éclogites et schistes blues): Données nouvelles sur la pétrologie des roches de la croute océanique subductée et des sédiments associés. Ph.D. dissertation, Université de Paris, Paris, pp. 177-238.

Kiénast, J. R., \& Nicot, E. (1971). Présence d'une paragenèse à disthène et chloritoïde (d'âge alpin probable) dans les gneiss à sillimanite, grenat et cordiérite de Valpelline (Val d'Aoste, Italie). Comptes Rendus de l'Académie des Sciences de Paris, $D$ 272, 1836-1840.

Lardeaux, J. M., Schwartz, S., Tricart, P., Paul, P., Guillot, S., Béthoux, N., et al. (2006). A crustal-scale cross-section of the southern-western Alps combining geophysical and geological imagery. Terra Nova, 18, 412-422.

Le Bayon, B., \& Ballèvre, M. (2006). Deformation history of a subducted continental crust (Gran Paradiso, Western Alps): Continuing crustal shortening during exhumation. Journal of Structural Geology, 28, 793-815.

Lemoine, M. (1971). Données nouvelles sur la série du Gondran près Briançon (Alpes cottiennes). Réflexions sur les problèmes stratigraphique et paléogéographique de la zone piémontaise. Géologie Alpine, 47, 181-201.

Malaspina, N., Scambelluri, N., Pennacchioni, G., \& Spagnolo, C. (2011). Fluid-induced plastic deformation in the crustal Austroalpine system (Western Italian Alps): A petrologic and fluid inclusions analysis. Italian Journal of Geosciences, 130, 61-74.

Malusà, M. G., Polino, R., Zattin, M., Bigazzi, G., Martin, S., \& Piana, F. (2005). Miocene to Present differential exhumation in the Western Alps: Insights from fission track thermochronology. Tectonics, 24, 1-23.

Manzotti, P. (2011). Petro-structural map of the Dent Blanche tectonic system between Valpelline and Valtournenche valleys, Western Italian Alps-1: 20 000, 1: 10 000, 1: 2500. Journal of Maps, 7, 340-352.

Manzotti, P. (2012). Polycyclic evolution in the Dent Blanche Tectonic System. Ph.D. dissertation, Universität Bern, Bern, Switzerland.

Manzotti, P., Ballèvre, M., Zucali, M., Robyr, M. \& Engi, M. (2014). The tectonometamorphic evolution of the Sesia-Dent Blanche nappes (internal Western Alps): Review and synthesis. Swiss Journal of Geosciences (in press).

Manzotti, P., Rubatto, D., Darling, J., Zucali, M., Cenki-Tok, B., \& Engi, M. (2012). From Permo-Triassic lithospheric thinning to Jurassic rifting at the Adriatic margin: Petrological and geochronological record in Valtournenche (Western Italian Alps). Lithos, 146-147, 276-292.

Manzotti, P., \& Zucali, M. (2013). The pre-Alpine tectonic history of the Austroalpine continental basement in the Valpelline unit (Western Italian Alps). Geological Magazine, 150, 153-172.

Marotta, A. M., \& Spalla, M. I. (2007). Permian-Triassic high thermal regime in the Alps: Result of late Variscan collapse or continental rifting? Validation by numerical modelling. Tectonics, 26, 1-27.

Maruyama, S., Cho, M., \& Liou, J. G. (1986). Experimental investigations of blueschist-greenschist transition equilibria: Pressure dependence of $\mathrm{Al}_{2} \mathrm{O}_{3}$ content in sodic amphibolesa new geobarometer. Geological Society of America, 164, $1-16$.

Masini, E., Manatschal, G., Mohn, G., Ghienne, J. F., \& Lafont, F. (2011). The tectono-sedimentary evolution of a supra-detachment rift basin at a deep-water magma-poor rifted margin: The example of the Samedan Basin preserved in the Err nappe in the SE Switzerland. Basin Research, 23, 652-677.

Mattirolo, O. (1901). Rilevamenti geologici del 1899-1900. Bollettino del Regio Comitato Geologico Ialiano (parte ufficiale), 32, $25-29$.

Menegon, L., Pennacchioni, G., Heilbronner, R., \& Pittarello, L. (2008). Evolution of quartz microstructure and c-axis 
crystallographic preferred orientation within ductively deformed granitoids (Arolla unit, Western Alps). Journal of Structural Geology, 30, 1332-1347.

Miller, C., \& Thöni, M. (2009). The "Permian event" in the Eastern European Alps: Sm-Nd and P-T data recorded by multi-stage garnet from the Plankogel unit. Chemical Geology, 260, 20-36.

Milnes, A. G. (1974). Post-nappe folding in the western Lepontine Alps. Eclogae Geologicae Helvetiae, 67, 333-348.

Mohn, G., Manatschal, G., Masini, E., \& Müntener, O. (2011). Riftrelated inheritance in orogens: A case study from the Austroalpine nappes in Central Alps (SE-Switzerland and N-Italy). International Journal of Earth Sciences, 100, 937-961.

Monjoie, P., Bussy, F., Lapierre, H., \& Pfeifer, H. R. (2005). Modeling of in situ crystallization processes in the Permian mafic layered intrusion of Mont Collon (Dent Blanche nappe, western Alps). Lithos, 83, 317-346.

Nervo, R., \& Polino, R. (1976). Un lembo di cristallino Dent-Blanche alla Torre Ponton (Valle d'Aosta). Bollettino della Società Geologica Italiana, 95, 647-657.

Nicot, E. (1977). Les roches méso- et catazonales de la Valpelline (nappe de la Dent Blanche, Alpes Italiennes). Ph.D. dissertation, Université de Paris, Paris.

Paganelli, E., Compagnoni, R., Nervo, R. \& Tallone, S. (1995). Il lembo Austroalpino di Eaux Rousses e le sue relazioni con la Zona Ofiolitica Piemontese nell'alta Valle di Cogne, Valle d'Aosta meridionale. In R. Polino e R. Sacchi (Eds), Atti convegno Alpi-Appennino, Peveragno 1994 (14, 335-348 pp.). Accademia Nazionale delle Scienze dei XL, Scritti e Documenti.

Paquette, J.-L., Chopin, C., \& Peucat, J.-J. (1989). U-Pb zircon, Rb-Sr and Sm-Nd geochronology of high to very-high-pressure metaacidic rocks from the western Alps. Contributions to Mineralogy and Petrology, 101, 280-289.

Pennacchioni, G. (1990). Evoluzione strutturale del M. Emilius (Austroalpino, Alpi Occidentali). Rendiconti della Società Geologica Italiana, 14, 97-100.

Pennacchioni, G., \& Cesare, B. (1997). Ductile-brittle transition in pre-Alpine amphibolite facies mylonites during evolution from water-present to water-deficient conditions (Mont Mary nappes, Italian Western Alps). Journal of Metamorphic Geology, 15, 777-791.

Pennacchioni, G., Di Toro, G., \& Mancktelow, N. S. (2001). Straininsensitive preferred orientation of porphyroclasts in Mont Mary mylonites. Journal of Structural Geology, 23, 1281-1298.

Pennacchioni, G., \& Guermani, A. (1993). The mylonites of the Austroalpine Dent Blanche nappe along the northwestern side of the Valpelline Valley (Italian Western Alps). Memorie di Scienze Geologiche, 45, 37-55.

Pfiffner, A. (2009). Geologie der Alpen. Bern: Haupt Verlag.

Rebay, G., Spalla, M. I., \& Zanoni, D. (2012). Interaction of deformation and metamorphism during subduction and exhumation of hydrated oceanic mantle: Insights from the Western Alps. Journal of Metamorphic Geology, 30, 687-702.

Regis, D., Rubatto, D., Darling, J., Cenki-Tok, B., Zucali, M. \& Engi, M. (2014). Multiple metamorphic stages within an eclogitefacies terrane (Sesia Zone, Western Alps) revealed by $\mathrm{U} / \mathrm{Th}-\mathrm{Pb}$ petrochronology. Journal of Petrology (in press).

Reinecke, T. (1998). Prograde high- to ultrahigh-pressure metamorphism and exhumation of oceanic sediments at Lago di Cignana, Zermatt-Saas Zone, western Alps. Lithos, 42, 147-189.

Roda, M., \& Zucali, M. (2008). Meso and microstructural evolution of the Mont Morion metaintrusives complex (Dent Blanche nappe, Austroalpine domain, Valpelline, Western Italian Alps). Italian Journal of Geosciences, 127, 105-123.

Roda, M., \& Zucali, M. (2011). Tectono-metamorphic map of the Mont Morion Permian metaintrusives (Mont Morion-Mont
Collon-Matterhorn Complex, Dent Blanche Unit), Valpelline-Western Italian Alps-1:10 000. Journal of Maps, 7, $519-535$.

Roesli, F. (1946). Sedimentäre Zone von Samaden (Kt. Graubünden). Eclogae Geologicae Helvetiae, 38, 329-336.

Rubatto, D., Regis, D., Hermann, J., Boston, K., Engi, M., Beltrando, M., et al. (2011). Yo-Yo subduction recorded by accessory minerals in the Sesia Zone, Western Alps. Nature Geoscience, $241,38-61$.

Sartori, M. (1987). Structure de la zone du Combin entre les Diablons et Zermatt (Valais). Eclogae Geologicae Helvetiae, 80, 789-814.

Schuster, R., \& Stüwe, K. (2008). Permian metamorphic event in the Alps. Geology, 36, 603-606.

Spalla, M. I., Lardeaux, J. M., Dal Piaz, G. V., Gosso, G., \& Messiga, B. (1996). Tectonic significance of Alpine eclogites. Journal of Geodynamics, 21, 257-285.

Sperlich, R. (1988). The transition from crossite to actinolite in metabasites of the Combin unit in Vallée St. Barthélemy (Aosta, Italy). Schweizerische Mineralogische und Petrographische Mitteilungen, 68, 215-224.

Steck, A., Della Torre, F., Keller, F., Pfeifer, H.-R., Hunziker, J. C., \& Masson, H. (2013). Tectonics of the Lepontine Alps: Ductile thrusting and folding in the deepest tectonic levels of the Central Alps. Swiss Journal of Geosciences, 106, 427-450.

Steck, A., \& Hunziker, J. C. (1994). The Tertiary structural and thermal evolution of the Central Alps-compressional and extensional structures in an orogenic belt. Tectonophysics, 238, 229-254.

Stella, A. (1905). Il problema geo-tettonico dell'Ossola e del Sempione. Bollettino del Regio Comitato Geologico Ialiano, $36,5-41$.

Stutz, A. H., \& Masson, R. (1938). Zur Tektonik der Dent Blanche Decke. Schweizerische Mineralogische und Petrographische Mitteilungen, 18, 40-53.

Vannay, J. C., \& Allemann, R. (1990). La zone piémontaise dans le Haut-Valtournanche (Val d'Aoste, Italie). Eclogae Geologicae Helvetiae, 83, 21-39.

Vavra, G., Gebauer, D., Schmid, R., \& Compston, W. (1996). Multiple zircon growth and recrystallization during polyphase Late Carboniferous to Triassic metamorphism in the Ivrea Zone (Southern Alps): An ion microprobe (SHRIMP) study. Contributions to Mineralogy and Petrology, 122, 337-358.

Vidal, O., De Andrade, V., Lewin, E., Munoz, M., Parra, T., \& Pascarelli, S. (2006). P-T deformation- $\mathrm{Fe}^{3+} / \mathrm{Fe}^{2+}$ mapping at the thin section scale and comparison with XANES mapping. Application to a garnet-bearing metapelite from the Sambagawa metamorphic belt (Japan). Journal of Metamorphic Geology, 24, 669-683.

Vidal, O., Parra, T., \& Vieillard, P. (2005). Thermodynamic properties of the Tschermak solid solution in Fe-chlorite: Application to natural examples and possible role of oxidation. American Mineralogist, 90, 347-358.

Weidmann, M., \& Zaninetti, L. (1974). Quelques données sur la série du Mont-Dolin (nappe de la Dent-Blanche, Valais). Eclogae Geologicae Helvetiae, 67, 597-603.

Whitney, D. L., \& Evans, B. W. (2010). Abbreviation for names of rock-forming minerals. American Mineralogist, 95, 185-187.

Wu, C., Wang, X., Yang, C., Geng, Y., \& Liu, F. (2002). Empirical garnet-muscovite geothermometry in metapelites. Lithos, 62, $1-13$.

Zucali, M., Manzotti, P., Diella, V., Pesenti, C., Risplendente, A., Darling, J., et al. (2011). Permian tectonometamorphic evolution of the Dent-Blanche Unit (Austroalpine domain, Western Italian Alps). Rendiconti online Società Geologica Italiana, 15, 133-136. 